Proc. Estonian Acad. Sci. Geol., 2004, 53, 2, 94-124

\title{
Redox changes in the deep shelf of the East Baltic Basin in the Aeronian and early Telychian (early Silurian)
}

\begin{abstract}
Enli Kiipli
Institute of Geology at Tallinn University of Technology, Estonia pst. 7, 10143 Tallinn, Estonia; enli.kiipli@egk.ee

Received 27 March 2003, in revised form 11 February 2004

Abstract. Aeronian black shales and overlying Telychian greenish-grey and red claystones of the deep shelf of the East Baltic Basin indicate different synsedimentary redox conditions of the bottom water of the sea. In the Aeronian, the primary bioproductivity rise caused accumulation of organicrich black shale in deep shelf and formation of microcrystalline limestone with chertification, chert nodules, and barite in shoreward areas. In the early Telychian, the bioproductivity decreased, as concluded from the absence of indicators of high primary bioproductivity in the Aeronian. The suggested mechanism regulating primary bioproductivity and oxygen content of bottom waters of deep shelf was a change from wind-induced upwelling in the Aeronian to downwelling in the Telychian. The sedimentation rate did not influence the change in the redox regime of the deep shelf sediment, as it was low for both the Aeronian and Telychian.
\end{abstract}

Key words: Aeronian, Telychian, East Baltic deep shelf, redox conditions, up- and downwellings.

\section{INTRODUCTION}

Differences in lithology, mineralogy, and rock chemistry evidence changes at the Aeronian-Telychian boundary. The changes concern sea water chemistry and early diagenesis of sediments with implication on hydrodynamic and atmospheric circulation, and palaeogeography. The area of investigation is southwest Estonia and west Latvia, which form a central, deeper part of the Palaeozoic East Baltic basin, treated here as the deep shelf. Waters below the surficial mixing zone, i.e. the deep shelf bottom waters, are under the study. In deep shelf the colour of rock is an indicator of redox conditions. Aeronian black shales are overlain by Telychian greenish-grey and red claystones. The black colour of the Aeronian 
shales is due to the occurrence of organic carbon and dispersed pyrite. The red colour of the Telychian rock is caused by hematite and minor amounts of goethite. Greenish-grey rocks lack ferric oxihydroxides, dispersed pyrite, and organic carbon. The colour of rock indicates a different redox regime of early diagenesis. The main early diagenetic factors are sea bottom water oxygenation, primary production of organic carbon, e.g. photosynthesized organic matter, its flux to the sea floor, and sedimentation rate. These factors have strong control over pore water composition and early diagenesis.

The aim of the present paper is to characterize the redox conditions of the deep shelf of the Aeronian and early Telychian on the basis of geochemical and mineralogical study of rock. Adjacent shallower facies, such as the limestones of the Saarde Formation of the Raikküla Stage, and limestones and marlstones of the Adavere Stage, contain geochemical and lithological indicators allowing tracing the processes in shoreward direction. Comparison of Aeronian and Telychian early diagenetic factors has revealed the regional and global mechanisms governing environmental changes.

Elucidation of the marine synsedimentary processes is possible. During the geological history of the East Baltic basin the sedimentary cover has not been affected by thermal processes. The formation of sediments in deep shelf excludes the change of colour to red due to subaerial weathering, though large gaps are present in geological sections (Nestor \& Nestor 2002). A red bed, e.g. hematite formation, due to subaerial weathering would have cut the facies boundaries, involving also shallower sediments. In our case red beds are located within the deep shelf, mainly in the claystone facies. Telychian marine red beds of the deep shelf are of primary origin, similar to the Ordovician red Jonstorp Formation (Männil 1966) and to the red clays of the present-day ocean. Aeronian black shales also preserve much of their initial chemical composition, though some decomposition of organic matter and removal of dissolved elements in the late diagenesis has been possible.

\section{PREVIOUS INVESTIGATIONS}

The analysis of ancient redox conditions is based largely upon the knowledge of the facies of the modern ocean (Murdmaa 1987; Tromp et al. 1995). Significant features of the Palaeozoic, such as prevailing anoxia of ocean deep waters (Berry et al. 1989), are considered. The model of early diagenesis (Berner 1971, 1980; Froelich et al. 1979) is taken as the starting point for tracing the geochemistry of the past marine environment. The Silurian East Baltic sedimentary basin is well characterized in terms of lithology and palaeontology (Kaljo 1970, 1977; Gailite et al. 1987; V. Nestor 1994; Paškevičius 1997; Raukas \& Teedumäe 1997). Figure 1 shows the correlations for the East Baltic. The chemical composition has been investigated for the black shale of the Dobele Formation (Kiipli 1997). On the basis of correlations of the black shale of the Dobele Formation and micritic 


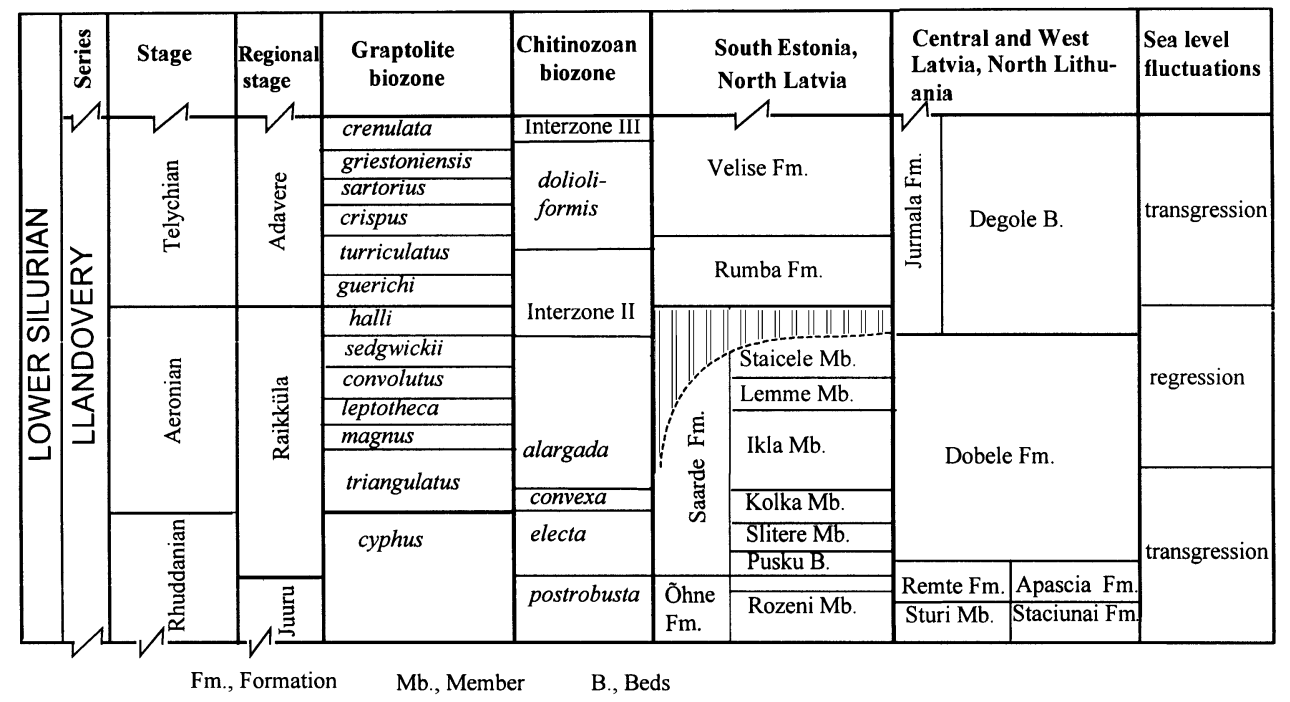

Fig. 1. Stratigraphy and correlation of the Llandovery rocks of the East Baltic. Sources: V. Nestor (1994), Nestor (1997), Kaljo \& Martma (2000), Loydell et al. (2003) for standard, regional, and Estonian units, Gailite et al. (1987) for Latvian, and Paškevičius (1997) for Lithuanian units.

limestone of the Saarde Formation, a primary bioproductivity rise for the late Rhuddanian-Aeronian has been proposed (Kiipli et al. 2004). The use of models based on isotope geology (Kroopnick 1985; Berger \& Vincent 1986) has allowed an insight into Silurian marine chemistry (Heath et al. 1998; Kaljo et al. 1998; Kaljo \& Martma 2000). Location of the Baltica Plate (Torsvik et al. 1992; Cocks 1993; Scotese 2001; Kiessling et al. 2003), prevailing winds (Ziegler et al. 1977), and upwellings (Parrish 1982; Moore et al. 1993) form a geological background for interpretations of processes.

\section{GEOLOGICAL BACKGROUND}

In the Llandovery terrigenous clays accumulated in the deep shelf. In the vicinity of the continental margin the shelf sediments were black or dark grey (Bassett et al. 1989), hinting at a decrease in the oxygen content of bottom waters transitional to the anoxic waters of the ocean deep (Berry et al. 1989). Starting from the late Rhuddanian cyphus Zone (Loydell et al. 2003), a tongue of black shales expanded to the west Latvian area. During the Aeronian, the formation of the black shale of the Dobele Formation was going on (Fig. 2). Contemporaneously micritic (cryptocrystalline) limestones of the Saarde Formation accumulated in the neighbourhood in the north as prograding side-fillings of distal shallow shelf (Nestor \& Einasto 1997). The up to $177 \mathrm{~m}$ thick limestone sequence correlates with $7 \mathrm{~m}$ of black shale. At their contact intercalation of limestone and black 


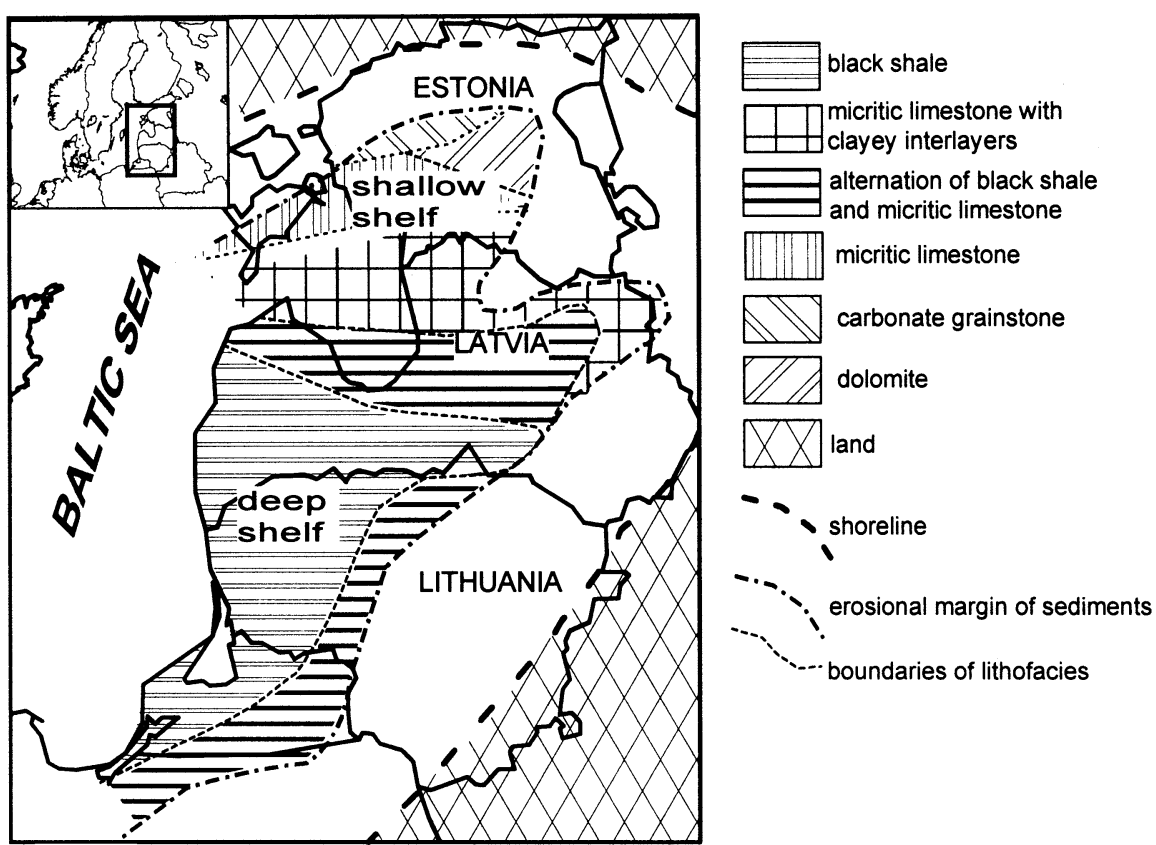

Fig. 2. Sketch-map showing the present distribution of the sediments of the Mid-Llandovery Ikla Member, Aeronian. Lithology with modification after Nestor \& Einasto (1997, fig. 147).

shale is recorded in boreholes. Palaeontological data confirm the above correlations (Gailite et al. 1987; Loydell et al. 2003; Nestor et al. 2003). In the southeastern direction the black shale is replaced by a hiatus in sedimentation (Paškevičius 1997).

The gaps in faunal successions of the shallow shelf cores evidence regressive basin development in the upper Aeronian (Einasto 1986; Nestor et al. 2003). Lagoonal dolostones alternating with bioclastic and micritic limestones of the Raikküla Stage of nearshore middle Estonian sections (Teedumäe et al. 2003) confirm shallowing of the basin. The claystones and marls of the Adavere Stage cover the carbonates of the Raikküla Stage transgressively (Fig. 3). The early Telychian transgression was contemporaneous in Baltica, South China, and North America (Johnson et al. 1991). Two successive pulses were distinguished in Estonian sections, the first corresponding to the Rumba Formation, the other to the Velise Formation (Nestor 1972; Johnson et al. 1991; Loydell 1998). In Latvia the lower part of the Telychian, the Degole Beds of the Jurmala Formation, contain red-coloured intervals (Fig. 4). Marine red beds occur in the lower part of the Velise Formation in south Saaremaa and in several cores of mainland southwestern Estonia. Telychian marine red beds are spread also in the Oslo and Ringerike district (Vik Formation) of Norway (Worsley et al. 1982), in England, Scotland, and South China (Holland \& Bassett 2002). 


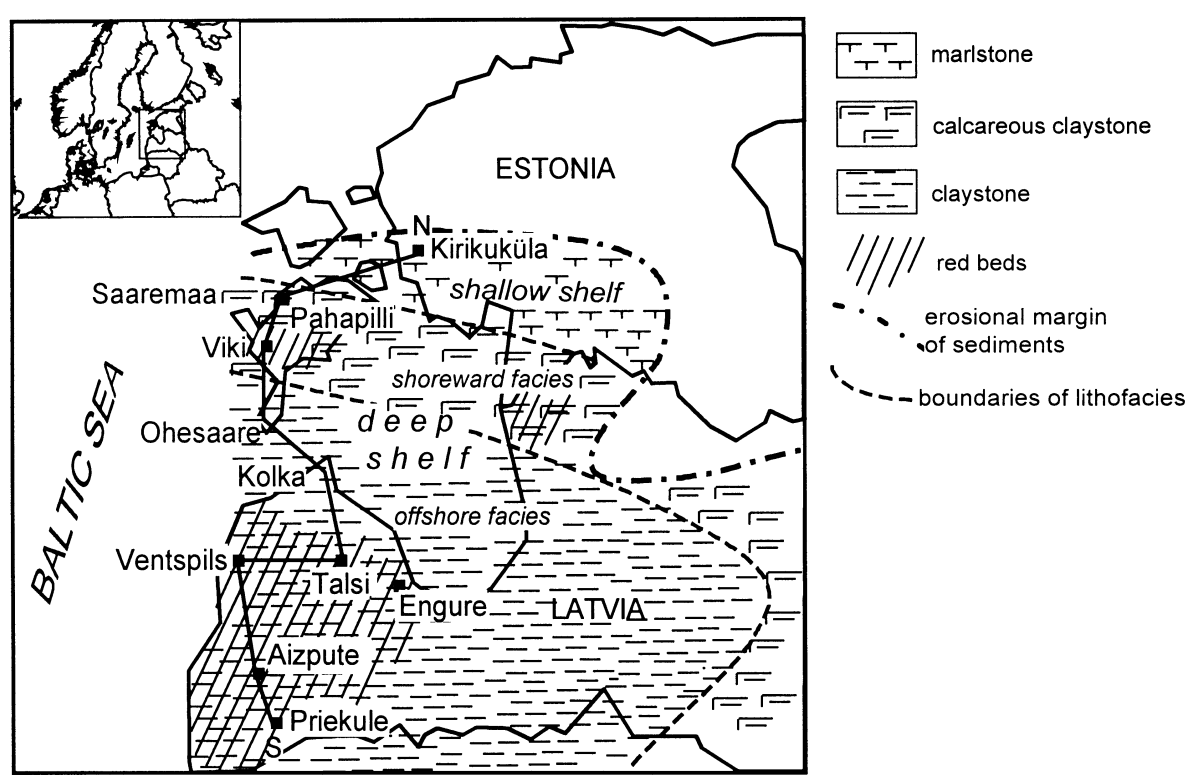

Fig. 3. Sketch-map of main facies boundaries and red bed occurrences in the Telychian, modified after Kaljo (1977, fig. 2). N-S, the line of the cross-section in Fig. 4.

\section{METHODS}

The rock samples were analysed for major and trace elements (Tables 1 and 2) by the X-ray fluorescence method in the laboratory of the Institute of Geology at Tallinn University of Technology, using discs fused with Li-tetraborate, and pressed-powder pellets. Fused discs were used for measuring the main chemical elements, pressed-powder pellets for trace elements and sulphur. Calibration was done after international and Estonian rock reference materials (T. Kiipli et al. 2000). The organic carbon content and petrophysical parameters of 13 Telychian samples were determined in the Geotechnical Laboratory of the Environmental Survey of Estonia (Table 3). The natural volume density was measured by the paraphination method. Organic $\mathrm{C}$ was measured according to the Tyurin oxidation method, which is equivalent to the Anne method used in the Western countries (van Ranst et al. 1999, cited in Reintam 2003). A rapid method for estimating the content of organic matter is the measuring of loss on ignition (LOI) at $450{ }^{\circ} \mathrm{C}$. At $450^{\circ} \mathrm{C}$ the organic matter burns out and crystal water of clay minerals and goethite volatilizes. Organic $\mathrm{C} \times 1.724$ gives the content of organic matter, which coincides with LOI $450^{\circ} \mathrm{C}$ at the values of organic $\mathrm{C}$ exceeding $5 \%$. At the lower values the agreement is poor. The ignition of samples at $920^{\circ} \mathrm{C}$ releases $\mathrm{CO}_{2}$ of carbonates and sulphur of pyrite in addition to organic matter and crystal water. 


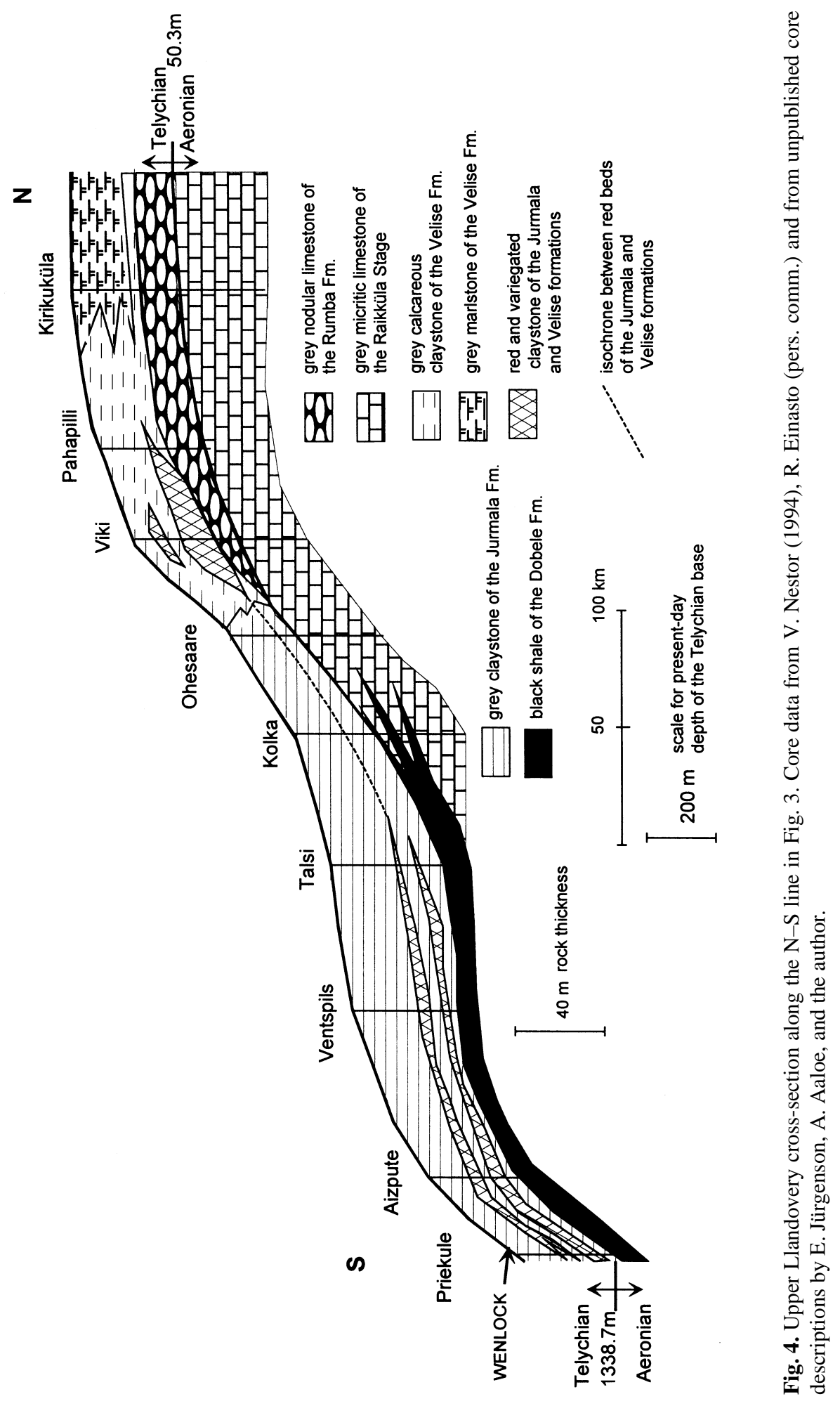




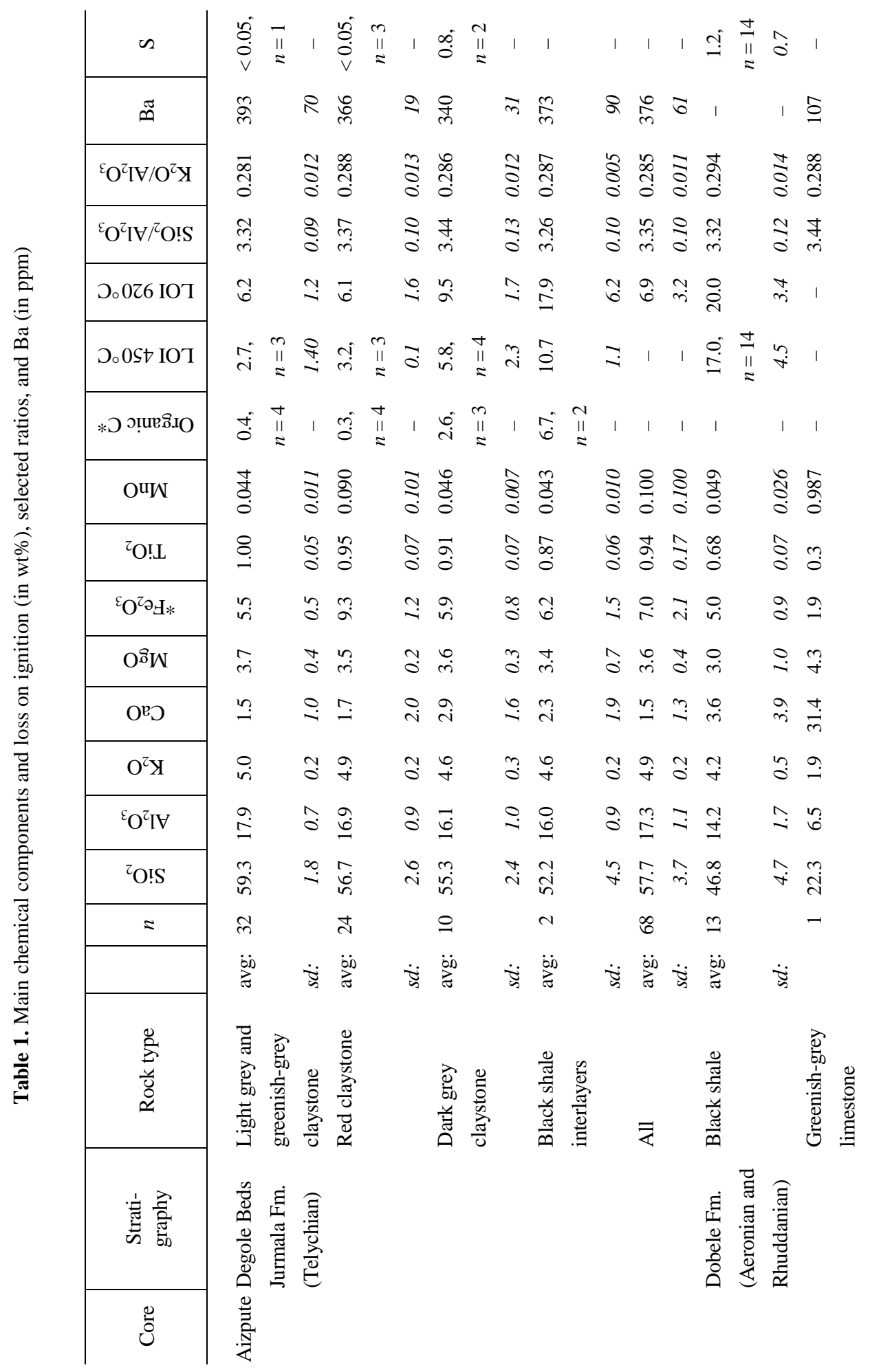




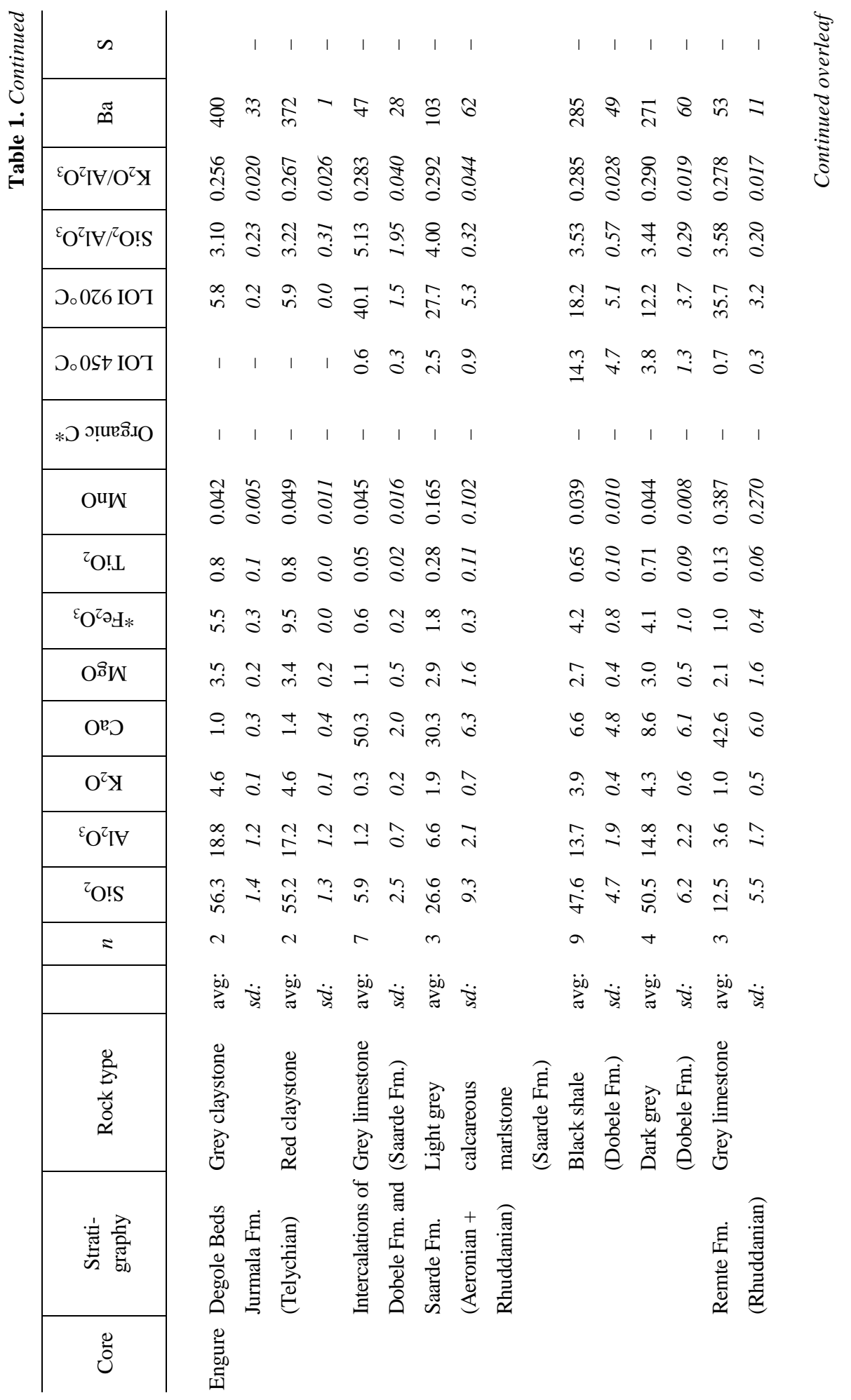




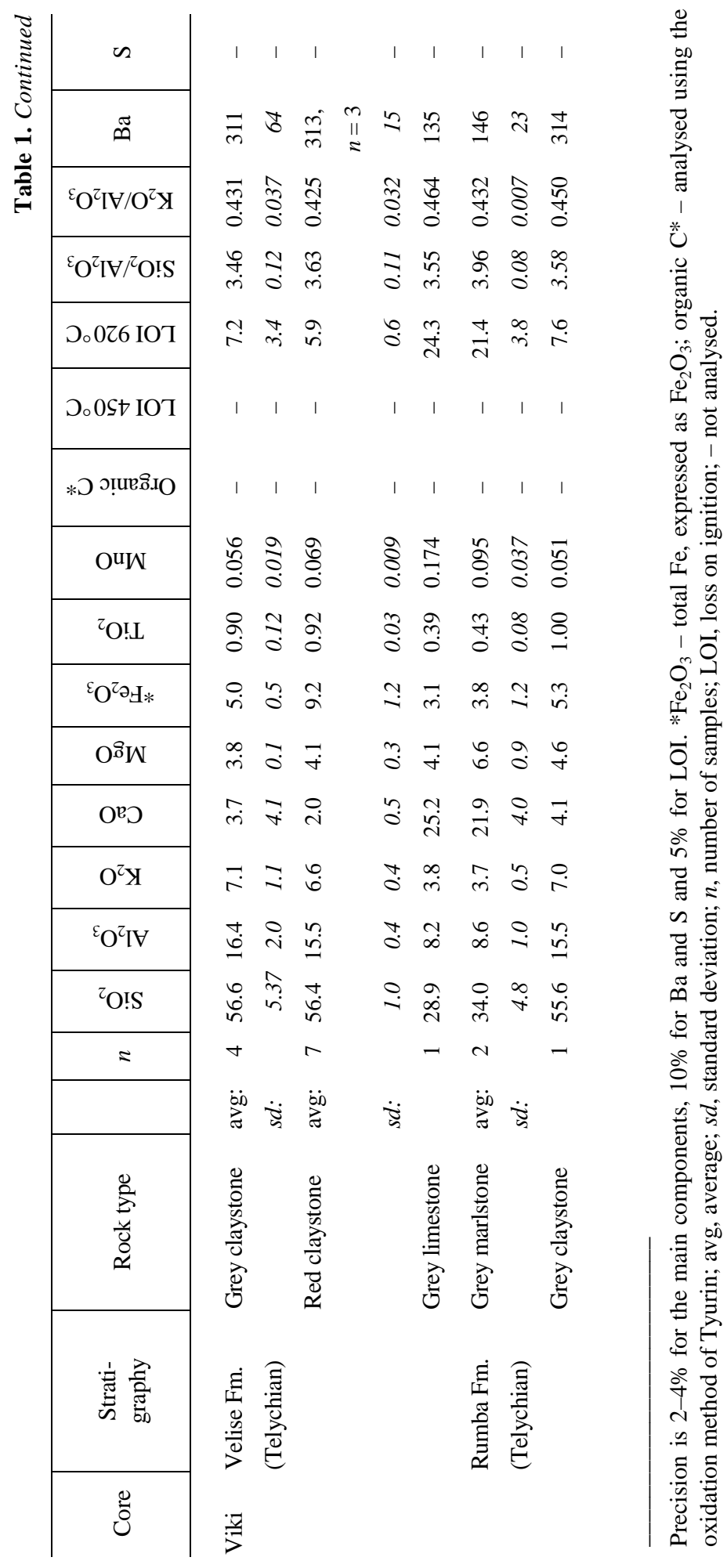




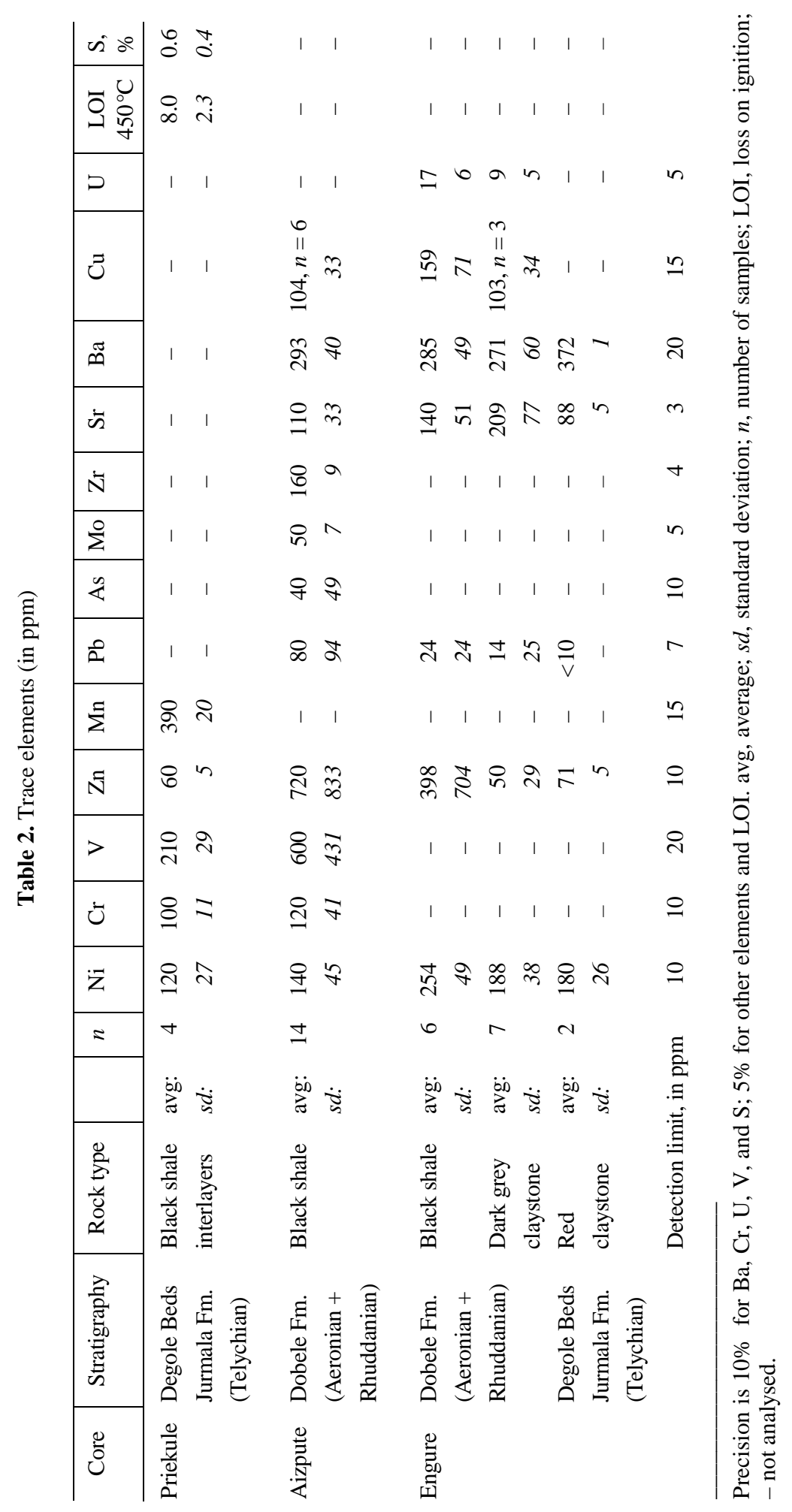


Table 3. Petrophysical properties and organic carbon content of the Telychian samples of the Aizpute core

\begin{tabular}{l|l|c|c|c|c|c|c|c}
\hline $\begin{array}{c}\text { Sample } \\
\text { (number } \\
\text { refers to } \\
\text { depth, m) }\end{array}$ & $\begin{array}{c}\text { Colour } \\
\text { of the rock }\end{array}$ & $\begin{array}{c}\text { Natural } \\
\text { moisture, } \\
\%\end{array}$ & $\begin{array}{c}\text { Natural } \\
\text { volume } \\
\text { density, } \\
\mathrm{g} / \mathrm{cm}^{3}\end{array}$ & $\begin{array}{c}\text { Dry } \\
\text { volume } \\
\text { density, } \\
\mathrm{g} / \mathrm{cm}^{3}\end{array}$ & $\begin{array}{c}\text { Dry } \\
\text { density, } \\
\mathrm{g} / \mathrm{cm}^{3}\end{array}$ & $\begin{array}{c}\text { Porosity, } \\
\%\end{array}$ & $\begin{array}{c}\text { Organic } \\
\text { carbon, } \\
\%\end{array}$ & $\begin{array}{c}\text { LOI at } \\
450^{\circ} \mathrm{C}, \\
\%\end{array}$ \\
\hline A951 & Dark grey & - & - & - & - & - & 2.96 & 5.0 \\
A952 & Red & 1.7 & 2.3 & 2.26 & 2.87 & 21.3 & 0.35 & - \\
A953 & Red & - & - & - & - & - & 0.21 & 3.1 \\
A953.98 & Dark grey & - & - & - & - & - & 1.15 & - \\
A958 & Red & - & - & - & - & - & 0.31 & - \\
A958 & Greenish-grey & - & - & - & - & - & 0.32 & - \\
A959 & Greenish-grey & - & - & - & - & - & 0.84 & 4.1 \\
A961.7 & Black & 2.2 & 2.11 & 2.06 & 2.58 & 20.2 & 6.62 & 10.1 \\
A962 & Dark grey & - & - & - & - & - & 3.74 & 7.5 \\
A963 & Greenish-grey & - & - & - & - & - & 0.24 & - \\
A963 & Black & 1.8 & 2.15 & 2.11 & 2.55 & 17.3 & 6.72 & 11.5 \\
A966.2 & Red & - & - & - & - & - & 0.2 & - \\
A968.2 & Greenish-grey & - & - & - & - & - & 0.19 & - \\
\hline
\end{tabular}

LOI, loss on ignition. Organic carbon analysed according to the Tyurin method. - not analysed.

\section{Theoretical background}

Berner's $(1971,1980)$ model of early diagenetic factors, which joins into a mathematical equation the sedimentation rate, concentration of oxygenating agents of marine water, concentration of organic carbon in the upper sediment layer, and degradation rate of the organic carbon, was taken as a theoretical basis in tracing redox conditions. This model is valid for modern sedimentary environments, where direct measurements of factors can be done. This theoretical approach is applicable to the geological past if the rock has preserved the early diagenetic signal. Berner's early diagenetic equation, reduced to the form that is most often used in vertical advective-diffusive sediment models (Tromp et al. 1995; see also Krauskopf \& Bird 1995 for a review), is

$$
\partial_{t} C=D \partial_{z}^{2} C-\omega \partial_{z} C+\sum R,
$$

where $t$ denotes time, $D$ is the diffusion-dispersion coefficient, $C$ is the concentration of dissolved or solid species in the sediment, $z$ is the depth below the sediment-water interface, $\omega$ is the sedimentation rate, $R$ is the net rate of concentration change due to chemical and biological sources and sinks. Expressing the net rate as the metabolic decay rate of organic matter, substituting it in the diagenetic equation, and solving the equation for $\mathrm{O}_{2}$ at the boundary conditions 


$$
\begin{aligned}
& z=0, \quad C=C_{o} \text { (concentration of free oxygen in overlying water) } \\
& z \rightarrow \infty, \quad C \rightarrow C_{\infty} \text { (concentration of } \mathrm{O}_{2} \text {, after reduction ceases), }
\end{aligned}
$$

we get the formula (Berner 1971)

$$
C_{o}=L G_{o} \omega^{2} /\left(D_{\mathrm{O}_{2}} k_{a e}+\omega^{2}\right)+C_{\infty},
$$

where $C_{o}$ is the concentration of bottomwater oxygen (in $\mu \mathrm{M} / \mathrm{cm}^{3}$ ), $G_{o}$ is the concentration of organic carbon in the sediment layer near the sediment-water interface (in $\mu \mathrm{M} / \mathrm{cm}^{3}$ ), $\omega$ is the sedimentation rate (in $\mathrm{cm} / \mathrm{y}, \mathrm{y}=$ year), $D_{\mathrm{O}_{2}}$ is the diffusion coefficient of $\mathrm{O}_{2}$ in sediment (in $\mathrm{cm}^{2} / \mathrm{y}$ ), $k_{a e}$ is the first-order rate constant for oxidation of organic carbon by $\mathrm{O}_{2}$ (in $\mathrm{y}^{-1}$ ) depending on the sedimentation rate (Tromp et al. 1995), and $L=1.3$ is the stoichiometric ratio of moles of $\mathrm{O}_{2}$ reduced over moles of carbon oxidized. The formula (2) represents the balance of factors for oxic conditions in the sediment. In the oxic regime the degradation of organic carbon uses only free oxygen, as it takes place in the red facies of the Telychian. To describe the organic carbon degradation in the case of black shale formation when most of the organic matter escapes decomposition, the equations for sulphate reduction and for methanogenesis are additionally needed. For the Telychian deep shelf geological section an attempt was made to estimate the role of each early diagenetic factor using proxies for them. Barium measurements were used as representatives for primary bioproductivity, $\mathrm{SiO}_{2} / \mathrm{Al}_{2} \mathrm{O}_{3}$ and $\mathrm{K}_{2} \mathrm{O} / \mathrm{Al}_{2} \mathrm{O}_{3}$ ratios as proxies for the sedimentation rate. These proxies are sensitive to diagenetic changes or may depend on other matters, therefore many aspects must be taken into account. The numerical value of the sedimentation rate was calculated for Telychian deep shelf claystone using the formula by Berner (1980), time estimation by Tucker \& McKerrow (1995) and Kaljo et al. (1998), and present-day porosity from Table 3 .

Aeronian conditions were estimated using $\mathrm{SiO}_{2} / \mathrm{Al}_{2} \mathrm{O}_{3}$ and $\mathrm{K}_{2} \mathrm{O} / \mathrm{Al}_{2} \mathrm{O}_{3}$ ratios as proxies for the sedimentation rate, $\delta^{13} \mathrm{C}$ and several other indicators (see below) as proxies for primary bioproductivity, and trace metal content and organic matter as indexes of anoxic bottom water.

\section{LITHOLOGY，MINERALOGY，AND GEOCHEMISTRY}

\section{Aeronian}

\section{Black shale}

The late Rhuddanian-Aeronian black shales of the Dobele Formation are laminated claystones containing organic carbon and more trace metals than the shale average (Gromet et al. 1984). Kiipli (1997) gives a characterization of the black shales of the Dobele Formation on the basis of the geochemistry and 
mineralogy of the Aizpute core (Fig. 2). The main rock-forming minerals of black shale are terrigenous quartz, illite, chlorite, and K-feldspar with the admixture of authigenic pyrite and $\mathrm{Ca}-\mathrm{Mg}$ carbonates. Some plagioclase and traces of kaolinite are recorded. The calculated carbonate content is from 3.5 to $10.3 \%$, on average 7.6\%. $\mathrm{CaO}$ increases upwards in the Aizpute section, showing an increase in calcite content. The pyrite content is $0.5-2 \%$. The organic matter is estimated on the basis of loss on ignition at $450^{\circ} \mathrm{C}$ (LOI), which in black shale is $12-25 \mathrm{wt} \%$, on average $17 \%$ (Table 1). Main chemical elements and $\mathrm{SiO}_{2} / \mathrm{Al}_{2} \mathrm{O}_{3}$ and $\mathrm{K}_{2} \mathrm{O} / \mathrm{Al}_{2} \mathrm{O}_{3}$ ratios are presented in Figs. 5 and 6. In the Aizpute core, the contents of trace elements $\mathrm{Cr}, \mathrm{Mo}, \mathrm{Ni}, \mathrm{Pb}, \mathrm{Zn}$, and $\mathrm{V}$ (Table 2) vary from the shale average to exceeding the average several times. Positive correlation between LOI and the contents of $\mathrm{Ni}, \mathrm{V}, \mathrm{Cr}$, and Mo is observed, the correlation coefficients being 0.85 , $0.79,0.75$, and 0.55 , respectively. The preserved organic matter, increased content of trace metals, and a fine millimetre-scale lamination of black shale speak about oxygen-poor or anoxic bottom water and anoxic conditions within the sediment. Sulphate reduction took place within the sediment and supposedly in the nearbottom water. The sulphur content of black shales is $0.5-3.2 \%$ (Fig. 6).

In the Engure core, black shale, dark grey claystone, and limestone alternate. The chemical composition of black shale is here similar to that of the Aizpute core (Tables 1 and 2). Dark grey layers are poorer in organic matter (LOI is 3.8\%); the lamination is absent, hinting at bioturbation and better oxygenation of bottom waters. Limestone intervals are represented by grey micritic or fine-crystalline rock, commonly containing dispersed pyrite. Organic matter, if present, gives dark coloration to the limestone. Limestone with dispersed pyrite and without organic carbon hints at oxygenating bottom water conditions with sulphate reduction within the sediment, characteristic of the shallower shelf. Supposedly the oxygen content of bottom water varied temporally. The carbonate sedimentation was also of various lateral extension, episodically reaching the deep shelf. Rare limestone interlayers within condensed black shales of the deep shelf are recorded in the Ventspils, Talsi, Pavilosta, Nitaure, and other West Latvian cores.

\section{Micritic limestone of the Saarde Formation}

The micritic (cryptocrystalline) limestone of the Saarde Formation (Raikküla Stage, late Rhuddanian-Aeronian) is distributed in western, central, and southern Estonia. Micritic limestone is a light grey rock consisting of low-magnesian calcite barren of shelly fauna. The content of the siliciclastic compound is 5-8\%. The limestone is formed in the presence of oxygenated bottom waters with sulphate reduction within the sediment, as shown by dispersed pyrite occurrences in the limestone. The accumulation has taken place far below the wave-base.

Chert occurrences in the form of nodules are well known in carbonate rocks of the Raikküla Stage (Jürgenson 1958, 1974). Recently, chertified rims in limestone layers near bedding planes, or disseminated spherules of millimetre-scale diameter were discovered (Kiipli et al. 2004). In modern oceans silica production covaries 


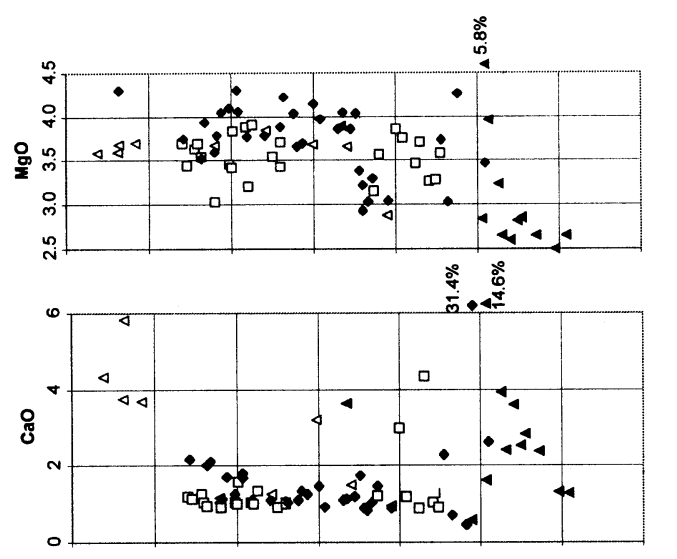

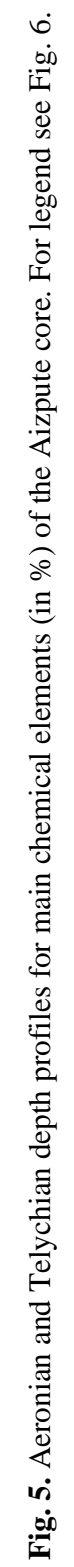

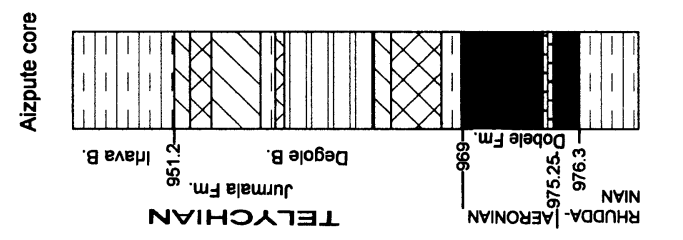



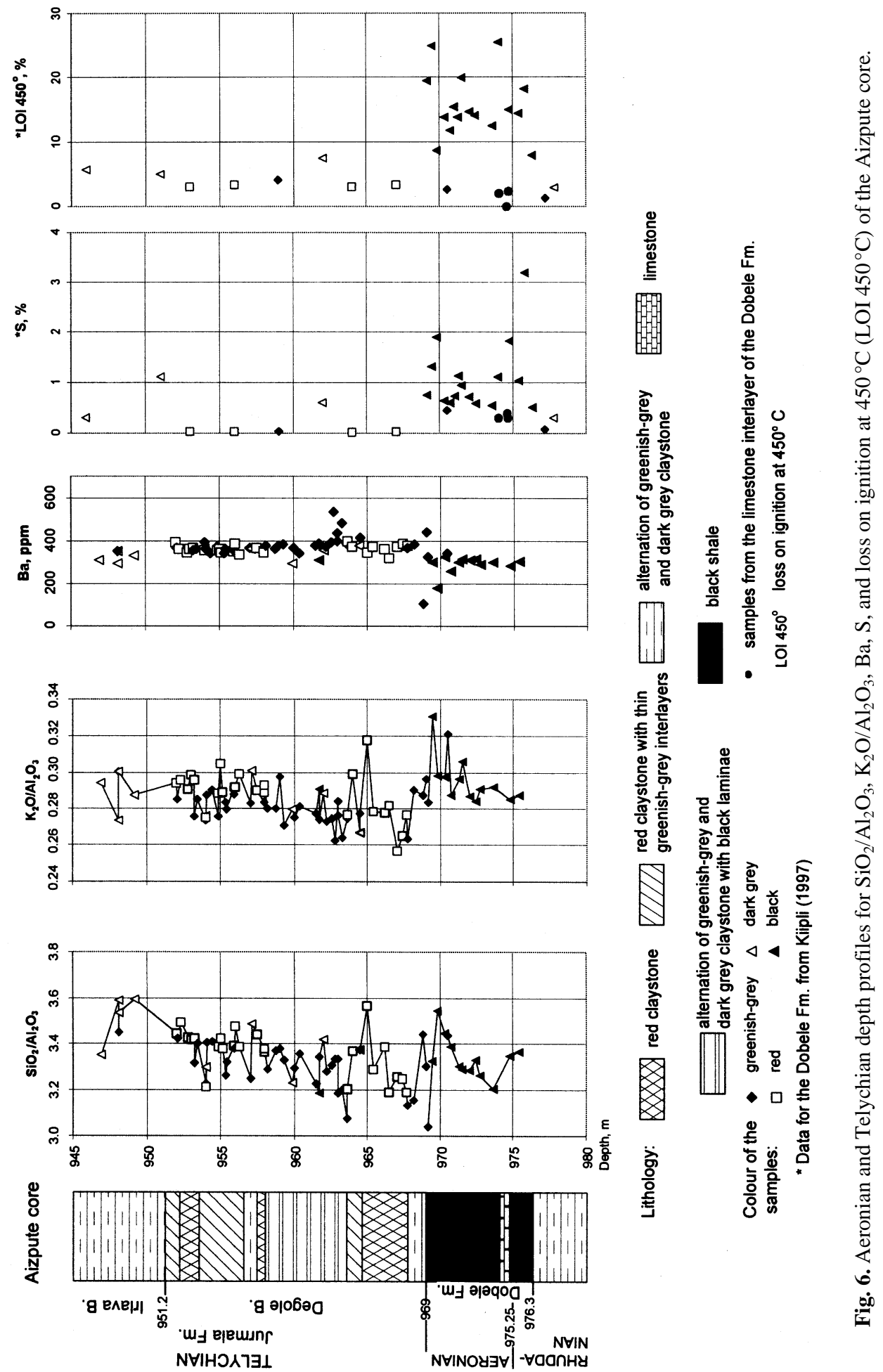
with primary productivity (Thunell et al. 2000). Micritic limestones contain barite, formed at the expense of $\mathrm{Ba}$ scavenged to the frustules of silica-producing planktonic organisms during their fall through the water column. Barite is also considered as a proxy for bioproductivity (Bishop 1988; Dymond et al. 1992). Small, 1-2\%o increases in $\delta^{13} \mathrm{C}$ have been interpreted as an index of rise of primary bioproductivity in surficial waters (Berger \& Vincent 1986). The increase in $\delta^{13} \mathrm{C}$ of up to $3.7 \%$ in the middle of the Ikla Member in the Ruhnu core, recorded by Kaljo \& Martma (2000), is reinterpreted by the author as a reflector of the increased primary bioproductivity. The main conclusion, based on correlative black shale of the Dobele Formation and micritic limestone of the Saarde Formation containing chertification, barite occurrences, and increased $\delta^{13} \mathrm{C}$, is that the Aeronian in the East Baltic was a period of high primary bioproductivity (Kiipli et al. 2004).

\section{Telychian}

The Telychian in western Latvia is represented by the Jurmala Formation consisting of the Degole Beds in the lower and Irlava Beds in the upper part. We focus on the Degole Beds. The boundary between the Jurmala and Dobele formations is defined as the boundary between black shale and greenish-grey claystone. The graptolites of the halli Zone were not found here (Loydell et al. 2003), which shows that the boundary between the Aeronian and Telychian is either in a gap or within the greenish-grey basal part of the Degole Beds, where graptolites are lacking due to unsuitable living or preservation conditions. In Estonia the Telychian corresponds to the Adavere Stage consisting of the Rumba and Velise formations (Fig. 1).

\section{Telychian red and greenish-grey beds of the deep shelf}

The 17-20 m thick Degole Beds of the Jurmala Formation consist of red and grey rocks in western Latvian cores (Fig. 3). A 5-13 m thick grey unit containing greenish-grey and dark grey layers with rare thin $0.5 \mathrm{~cm}$ interlayers of finely laminated black shales divides the varicoloured, mostly red claystone section into two parts (Fig. 4). The Degole Beds are overlain by the grey Irlava Beds with the upwards gradually increasing carbonate content.

Mineralogy and geochemistry were studied in the Aizpute core. The Degole Beds consist predominantly of claystone with few carbonate layers. Main terrigenous minerals are quartz, illite, chlorite, K-feldspar, and minor plagioclase. The authigenic minerals hematite and goethite occur in red intervals (Kiipli et al. 2000a). In claystones the content of carbonates, represented mostly by dolomite, is low. The average $\mathrm{CaO}$ content is $2.2 \%$ (standard deviation 3.8), and that of $\mathrm{MgO}, 3.6 \%$ (sd 0.4) (Table 1). Main chemical components $\mathrm{SiO}_{2}, \mathrm{Al}_{2} \mathrm{O}_{3}, \mathrm{~K}_{2} \mathrm{O}$, and $\mathrm{TiO}_{2}$ vary only little. Variation of $\mathrm{Fe}, \mathrm{S}$, and organic matter depends on redox conditions of 
the sedimentary environment. The Fe content, expressed as $\mathrm{Fe}_{2} \mathrm{O}_{3 \text { total }}$, is higher in red rocks (average 9.3\%) due to the presence of hematite and goethite. The content of ferric oxihydroxides (hematite + goethite) is $1.8-3.8 \%$ in red terrigenous claystones (on average $2.3 \%$, including $1.7 \%$ hematite and $0.6 \%$ goethite) and $5.6 \%$ (as hematite) in thin violet layers of altered volcanic ash, metabentonites (Kiipli et al. 2000a). The hematite occurrence in metabentonites evidences that hematite and goethite of red beds are formed in situ, not transported from land. Greenishgrey rocks have an average Fe content of 5.4\%, greenish-grey metabentonites $3.6 \%$, (expressed as $\mathrm{Fe}_{2} \mathrm{O}_{3 \text { total }}$ ). In greenish-grey rocks $\mathrm{Fe}$ is mostly bound in terrigenous clay minerals. Ferric oxihydroxides are absent. In red and greenish-grey rocks sulphur is below the detection limit, $0.05 \%$. Greenish-grey rock may contain crystals of coarse euhedral pyrite, but not dispersed pyrite. The absence of dispersed pyrite refers to the lack of sulphate reduction within the sediment. Nitrate and $\mathrm{Fe}(\mathrm{III})$ reduction is characteristic of greenish-grey rock. Red colour points to the absence of or minor $\mathrm{Fe}(\mathrm{III})$ reduction, as evidenced by $\mathrm{Mn}$ reduction of red metabentonites (Kiipli et al. 2000b). Dispersed pyrite and higher S contents are recorded in dark grey and black interlayers from the claystone interval dividing the red beds into the upper and lower parts. Dispersed pyrite refers to sulphate reduction within fresh sediment. The content of organic carbon is $1.2-3.7 \%$ in dark grey claystone (3 samples) and 6.6-6.7\% in two black shale interlayers (Table 3). Trace metals in the thin black interlayers were measured in the Priekule core. The contents of $\mathrm{Cr}$ and $\mathrm{Ni}$ are nearly the same, of $\mathrm{V}$ and $\mathrm{Zn}$ lower in the Degole Beds of the Priekule core compared to the black shale average in the Dobele Formation of the Aizpute core (Table 2).

The Ba content of the Telychian rocks of the Aizpute core was rather low and even, on average $376 \mathrm{ppm}$ (Table 1). Most of the barium was obviously bound in the lithogenic component. In three greenish-grey samples from the grey interval the Ba content was up to 483, 537, and 705 ppm (Fig. 6). This might be connected with the presence of biobarium. In the Viki core, Ba varied from 130 to $376 \mathrm{ppm}$, depending on "dilution" by carbonates.

\section{Telychian carbonates and claystones of the shoreward deep shelf}

The Aeronian carbonate accumulation was replaced by mainly terrigenous clay or marl deposition in the Telychian. The deep shelf expanded at the expense of previous shallow shelf areas due to the transgression in the Telychian. The Viki core from western Saaremaa is a good example, showing the change in sedimentation in the course of water deepening: upper Rhuddanian micritic limestones of the Raikküla Stage are unconformably overlain by nodular limestones of the Rumba Formation corresponding to the first pulse of Telychian transgression. Upwards, red claystones of the Velise Formation appear, corresponding to the second pulse.

The chemical composition of the red claystone of the Velise Formation was similar to that of the Degole Beds (Table 1). In the Viki core the $\mathrm{CaO}$ content was $3 \%$ higher than in the Aizpute core. 
The average $\mathrm{SiO}_{2} / \mathrm{Al}_{2} \mathrm{O}_{3}$ and $\mathrm{K}_{2} \mathrm{O} / \mathrm{Al}_{2} \mathrm{O}_{3}$ ratios (Fig. 7) were higher in the Viki core than in the Aizpute core (Fig. 6) (particularly the $\mathrm{K}_{2} \mathrm{O} / \mathrm{Al}_{2} \mathrm{O}_{3}$ ratio, 0.430). This means that the amount of K-feldspar referring to silt-size terrigenous fraction was higher in the onshore Viki core than in the offshore Aizpute core.

The hematite and goethite content of the red rocks of the Velise Formation was about $2 \%$, that is, on average $0.3 \%$ less than in offshore red rocks (Kiipli et al. 2000a). The thickness of the red-coloured layers decreased shoreward and at last only metabentonites revealed the red colour (Valjala core). The Telychian rocks of the shallow facies of north and central mainland Estonia, the Rumba as well as the Velise Formation, were mostly light grey in colour and contained dispersed pyrite.

\section{DISCUSSION}

\section{Sedimentation rate}

The sedimentation rate is one of the factors triggering the redox conditions within the sediment. In the present-day ocean red clays form in pelagic areas with the smallest sedimentation rate. If the sedimentation rate increases, the red colour disappears and sediments turn grey, as in the hemipelagic areas. The sedimentation rate regulates the burial and degradation of organic carbon. Rate constants of aerobic and anaerobic degradation decrease with the decreasing sedimentation rate (Tromp et al. 1995). In areas of a lower sedimentation rate the relative portion of organic carbon resistant to bacterial consumption increases, as decomposition preferentially removes the most reactive fraction from the plankton. The ratios of $\mathrm{SiO}_{2} / \mathrm{Al}_{2} \mathrm{O}_{3}$ and $\mathrm{K}_{2} \mathrm{O} / \mathrm{Al}_{2} \mathrm{O}_{3}$ allow us to estimate the

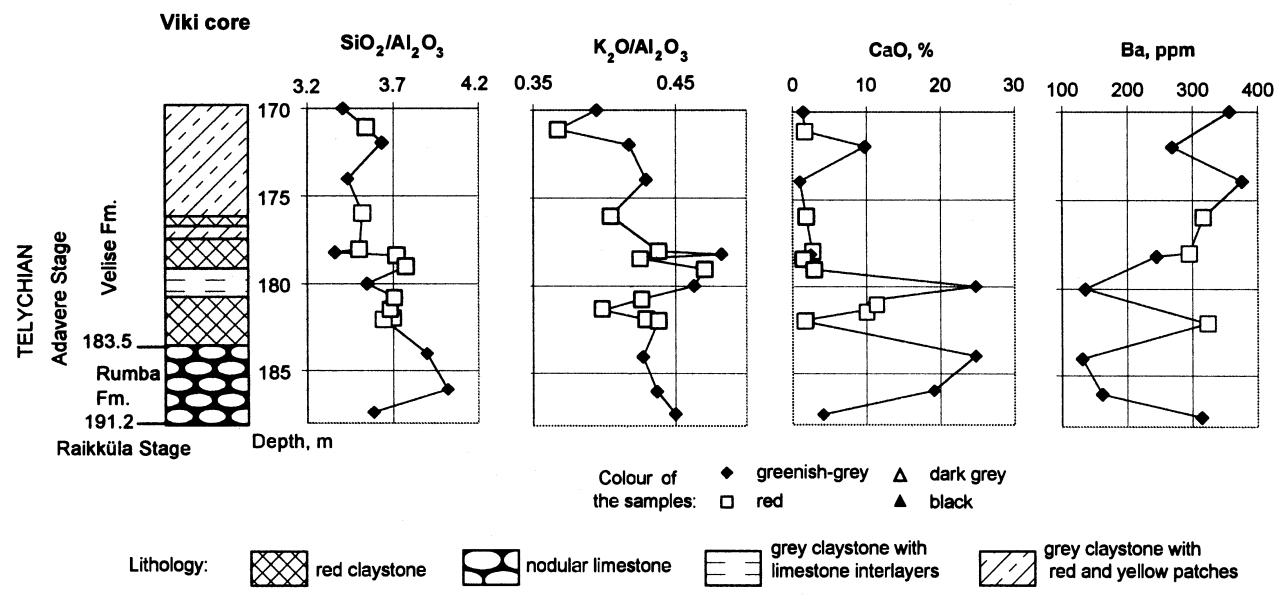

Fig. 7. Lithology of the Telychian section of the Viki core with depth profiles for $\mathrm{SiO}_{2} / \mathrm{Al}_{2} \mathrm{O}_{3}$, $\mathrm{K}_{2} \mathrm{O} / \mathrm{Al}_{2} \mathrm{O}_{3}, \mathrm{CaO}$, and $\mathrm{Ba}$. 
(A)

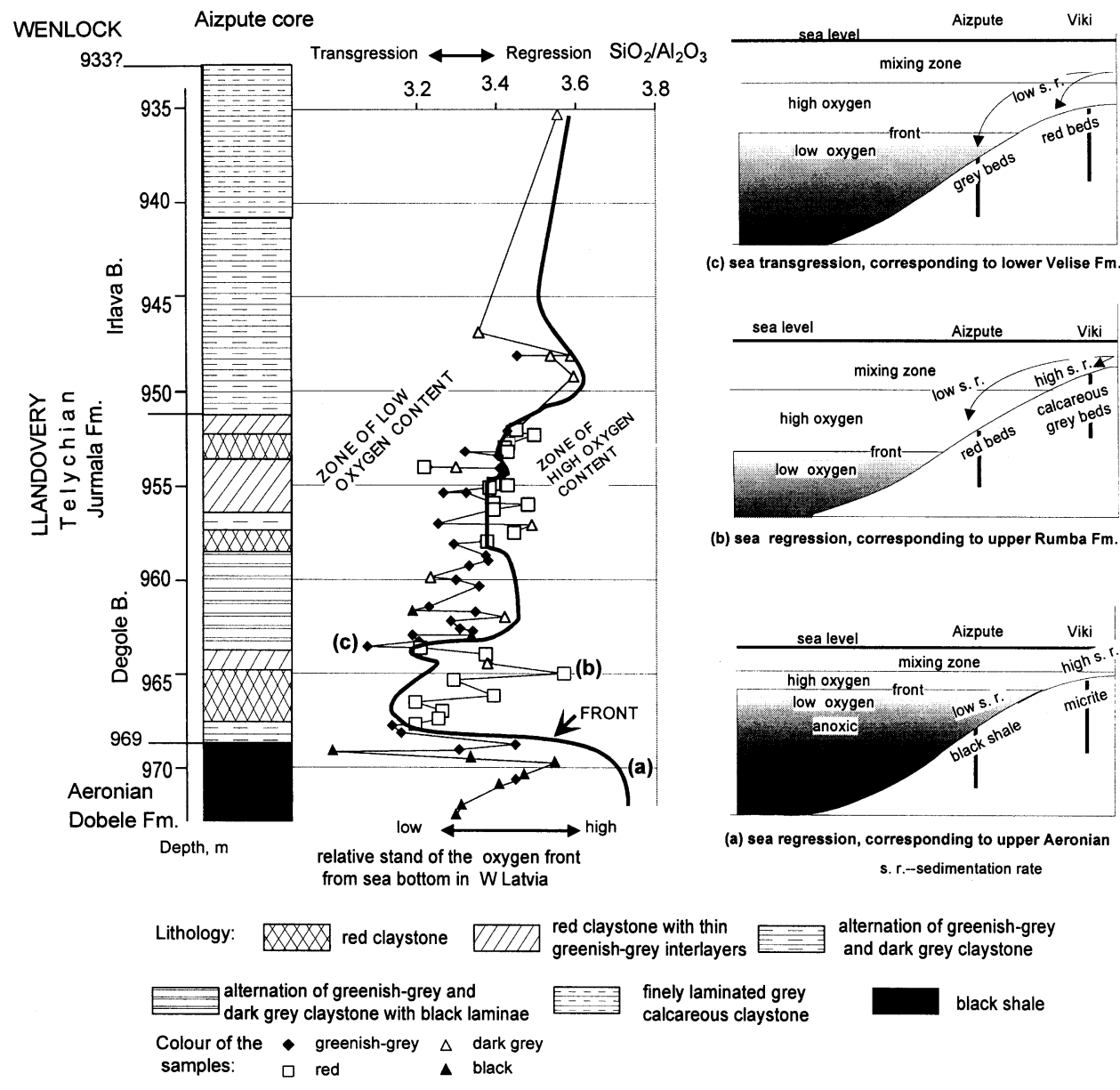

Fig. 8. (A) Lithological log and the $\mathrm{SiO}_{2} / \mathrm{Al}_{2} \mathrm{O}_{3}$ ratio through the Aeronian-Telychian boundary in the Aizpute core. Oscillation of the conditional high/low oxygen front in the water column against the background of eustatic sea level fluctuations is suggested. Red samples hint at their origination in the high-oxygen environment, greenish-grey samples hint at the low-oxygen environment. Black samples refer to deposition in anoxic bottom water conditions. Transgression-regression of the sea is estimated on the basis of $\mathrm{SiO}_{2} / \mathrm{Al}_{2} \mathrm{O}_{3}$. The model shows that sea level stand is not the cause of change in redox conditions at the Aeronian-Telychian boundary. (B) Schematic model of the environments of deposition depending on oxygen concentration referring to conditions (a), (b), and (c) in diagram (A). The lower red interval of the Degole Beds in the Aizpute core corresponds to the Rumba Formation in Estonian sections according to "O" - metabentonite correlation (Kiipli et al. 2000b).

stability of the terrigenous input rate (Figs. 6-8). The $\mathrm{SiO}_{2} / \mathrm{Al}_{2} \mathrm{O}_{3}$ and $\mathrm{K}_{2} \mathrm{O} / \mathrm{Al}_{2} \mathrm{O}_{3}$ ratios reflect the relationships between terrigenous compounds - quartz, $\mathrm{K}$-feldspar, and clay. This approach is valid if authigenic minerals containing $\mathrm{Si}, \mathrm{K}$, and $\mathrm{Al}$ 
are absent. For example, for the Saarde Formation the authigenic chert occurs in the carbonates of the Ruhnu core (Kiipli et al. 2004), so the $\mathrm{SiO}_{2} / \mathrm{Al}_{2} \mathrm{O}_{3}$ ratio reflects other qualities than terrigenous input alone. If using the $\mathrm{SiO}_{2} / \mathrm{Al}_{2} \mathrm{O}_{3}$ and $\mathrm{K}_{2} \mathrm{O} / \mathrm{Al}_{2} \mathrm{O}_{3}$ ratios as indicators of terrigenous matter, the lower ratios are characteristic of a finer grain size, higher ratios of a coarser grain size. It is possible to consider the ratios also as indicators of the sedimentation rate, which depend on the distance from the clastic source area. Transgressions and regressions influence the distance, being thereby related to the sedimentation rate.

The $\mathrm{SiO}_{2} / \mathrm{Al}_{2} \mathrm{O}_{3}$ and $\mathrm{K}_{2} \mathrm{O} / \mathrm{Al}_{2} \mathrm{O}_{3}$ ratios may reflect also a change in the terrigenous mineral composition and content due to the different terrestrial weathering conditions. The XRD study has shown that the composition of the Aeronian and Telychian terrigenous minerals is similar (Kiipli 1998), except for kaolinite, the traces of which have been detected in the clay fraction of the Aeronian deep shelf sediments (Kiipli 1997). Previous investigations have revealed the following clay minerals for the Silurian: illite (60-90\%), chlorite (5-40\%), and illite-smectite (5-20\%) (Jürgenson 1988). The proportions of terrigenous minerals are slightly variable, causing the variation in $\mathrm{SiO}_{2} / \mathrm{Al}_{2} \mathrm{O}_{3}$ and $\mathrm{K}_{2} \mathrm{O} / \mathrm{Al}_{2} \mathrm{O}_{3}$. Nevertheless, the variation in the mineralogical composition may hint at the influence of climate on the terrestrial weathering, but this needs further investigation.

Figure 6 reveals an increase in the $\mathrm{SiO}_{2} / \mathrm{Al}_{2} \mathrm{O}_{3}$ and $\mathrm{K}_{2} \mathrm{O} / \mathrm{Al}_{2} \mathrm{O}_{3}$ ratios in the upper half of the black shale section of the Aizpute core. Supposedly this shift corresponds to the end-Aeronian regression supported by a parallel trend of $\mathrm{Zr} / \mathrm{Al}_{2} \mathrm{O}_{3}$ (Kiipli 1997). In shallow-water sections the rocks of this time interval are absent. The decrease in the $\mathrm{SiO}_{2} / \mathrm{Al}_{2} \mathrm{O}_{3}$ and $\mathrm{K}_{2} \mathrm{O} / \mathrm{Al}_{2} \mathrm{O}_{3}$ ratios in the lower part of the Degole Beds reflects the first pulse of the lower Telychian transgression in the Aizpute core (Figs. 6 and 8). The $\mathrm{K}_{2} \mathrm{O} / \mathrm{Al}_{2} \mathrm{O}_{3}$ ratio in the Ruhnu core (Kiipli et al. 2004) shows a fall from 0.37 in the Velise Formation to 0.30 in the Saarde Formation, also hinting at the transgression. These examples confirm the link between the named ratios and eustatic movements. We therefore prefer to consider the changes in $\mathrm{SiO}_{2} / \mathrm{Al}_{2} \mathrm{O}_{3}$ and $\mathrm{K}_{2} \mathrm{O} / \mathrm{Al}_{2} \mathrm{O}_{3}$ at the Aeronian-Telychian boundary beds of the Aizpute core as related to the distance from the input source, but not to alternation of weathering conditions. The $\mathrm{SiO}_{2} / \mathrm{Al}_{2} \mathrm{O}_{3}$ and $\mathrm{K}_{2} \mathrm{O} / \mathrm{Al}_{2} \mathrm{O}_{3}$ ratios can be used as indicators of transgressions and regressions, and of the sedimentation rate. In estimating the sedimentation rate, additionally the carbonate content should be taken in account.

Past sedimentation rates cannot be measured directly, mainly because the time corresponding to the rock sequence is not precisely known and due to gaps in sedimentation. Approximate calculation for the whole Telychian of the Aizpute core yielded a mean sedimentation rate of $4 \mathrm{~cm} / \mathrm{ky}$ (Appendix). Excursions in $\mathrm{SiO}_{2} / \mathrm{Al}_{2} \mathrm{O}_{3}$ and $\mathrm{K}_{2} \mathrm{O} / \mathrm{Al}_{2} \mathrm{O}_{3}$ hint at some deviations from the average (Fig. 6).

Contradictions arise when comparing the sedimentation rates of the Aeronian and Telychian in the Aizpute core section. The $\mathrm{SiO}_{2} / \mathrm{Al}_{2} \mathrm{O}_{3}$ and $\mathrm{K}_{2} \mathrm{O} / \mathrm{Al}_{2} \mathrm{O}_{3}$ average 
values plus carbonate content do not differ substantially between the Aeronian and Telychian, hinting at possibly similar rates of sedimentation, but thicknesses of the corresponding sections differ up to 10 times (in the Aizpute core). Gaps are not found in the Dobele black shale section as the graptolite succession is complete, though condensed (Loydell et al. 2003). This leads to the problem whether the Aeronian is of much shorter duration than the Telychian (4 Ma for the Telychian according to Kaljo et al. 1998), or $\mathrm{SiO}_{2} / \mathrm{Al}_{2} \mathrm{O}_{3}$ and $\mathrm{K}_{2} \mathrm{O} / \mathrm{Al}_{2} \mathrm{O}_{3}$ are not comparable between different geological epochs in the sense of sedimentation rate. As in the Aeronian the sedimentation rate in the deep shelf was the same as in the Telychian or lower, it did not cause inversion of redox conditions at the Aeronian-Telychian boundary in deep shelf. This argument comes from the consideration that a low sedimentation rate promotes red bed and a high sedimentation rate black shale formation, if other conditions stay the same and water coloumn is oxygenated (Tromp et al. 1995).

\section{Oxygenation of sea water and sediment}

\section{Aeronian}

The chemical composition of Aeronian black shale indicates insufficiency of oxygen in deep shelf bottom waters. The preservation of fine lamination reflects the cease of bioturbation due to oxygen deficiency.

Anoxic conditions of the sea waters in general might be caused by the restricted water advection or by high planktonic production. The Ordovician-Early Silurian Baltic Basin was open to the ocean. The water depth was great in the PeriTornquist zone (Poprawa et al. 1999). Therefore, there is no reason to consider the Baltic Basin isolated during the Aeronian.

As the ocean deep waters were anoxic, their upwelling might have been one reason for anoxic bottom water conditions in the deep shelf. The other reason concerns primary productivity. Supposedly, the oxygen profile of the water column had depth-dependent descending gradient. The Kolka and Engure cores reflect the situation upwards on the shelf slope in the zone of oscillating oxygen content. Black shale layers formed in the anoxic, and grey limestones in the oxygenated bottom water conditions. Dark grey claystones and organic carbon containing limestones formed in the intermittent suboxic bottom water environment. Deeper in the sea, at the location of the Aizpute core, the bottom water was anoxic.

\section{Telychian}

The formation of the red bed in the Telychian replacing the Aeronian black shale, speaks about better oxygenation of deep shelf bottom water and sediment. In the red facies free oxygen was present within the sediment. Towards the continental slope the oxygen content of sea bottom waters supposedly decreased, as the contemporaneous Rasyte Formation in western Lithuanian cores and in 
cores of the Kaliningrad District was represented by dark claystones (Paškevičius 1997). These dark grey sediments in the outer shelf show that the flux of free oxygen into the red facies could not be from the direction of the ocean deep. Therefore the inversion of the oxygen regime of the ocean deep waters to the modern-ocean-like regime is excluded. Oxygen approached deep shelf from above, from the mixing zone of surface waters. The oxygen profile supposedly had a smoother depth-dependent decline than in the Aeronian. At the Aizpute site the oxygen content of bottom water decreased to the level at which $\mathrm{Fe}(\mathrm{III})$ reduction began, as evidenced by covariation of colour with $\mathrm{SiO}_{2} / \mathrm{Al}_{2} \mathrm{O}_{3}$ and $\mathrm{K}_{2} \mathrm{O} / \mathrm{Al}_{2} \mathrm{O}_{3}$ ratios. This covariation was revealed in the upper red-and-green interval of the Aizpute core (Figs. 6-8) - greenish-grey rocks have smaller ratios than adjacent red ones. Treating the $\mathrm{SiO}_{2} / \mathrm{Al}_{2} \mathrm{O}_{3}$ and $\mathrm{K}_{2} \mathrm{O} / \mathrm{Al}_{2} \mathrm{O}_{3}$ ratios as reflectors of transgressions and regressions, the alternation of red and green sediments can be explained by the location of the core site within the oscillations of the oxygen "front".

\section{Primary bioproductivity}

\section{Aeronian}

The organic carbon flux to the sediment surface is the third important factor influencing the sediment and seawater chemistry. As stated above, black shale in the deep shelf, contemporaneous micritic limestone formation, widespread chertification, barite occurrences, and $\delta^{13} \mathrm{C}$ positive mild shift in the shallower shelf were interpreted as indicators of high primary bioproductivity (Kiipli et al. 2004). The bioproductivity rise started in the late Rhuddanian with a $\delta^{13} \mathrm{C}$ value of $+1.5 \%$ and achieved a maximum of $+3.7 \%$ in early Aeronian mid-Ikla time, measured in the Ruhnu core (Kaljo \& Martma 2000). The primary bioproductivity decreased at the Dobele-Degole transition.

\section{Telychian}

Telychian carbonate rocks lack chert occurrences and barite. Organic-rich black shale receded from the deep shelf and micritic limestones were not formed. From the comparison with the Aeronian an important conclusion for the Telychian comes obvious: photosynthesized primary bioproductivity fell at the beginning of the Telychian. The decrease in bioproductivity was an important factor triggering the oxygenated sedimentary environment in the deep shelf. It is not known whether the decline in primary bioproductivity and the corresponding organic carbon flux to the sediment surface were sufficient to rearrange the oxygen regime in deep waters and favour red bed formation, or a mechanism bringing surplus oxygen to deep waters might be considered.

To estimate the relative change in primary bioproductivity, we measured the Ba content of rocks. Barite dissolves in anoxic sediment. In oxic sediment about 
$30 \%$ of barite is preserved (Dymond et al. 1992; De Lange et al. 1994). The Ba data were used as a palaeoproductivity proxy for red and greenish-grey rock, but the use of $\mathrm{Ba}$ was not efficient. The barite content was low (Fig. 6) due to small primary production of siliceous plankton and small thickness of the water column.

Another proxy for bioproductivity is $\delta^{13} \mathrm{C}$. Small fluctuations of $\delta^{13} \mathrm{C}(1$ or $2 \%$ ) may be interpreted as reflecting variations in primary bioproductivity. Together with $\delta^{18} \mathrm{O}$, the analysis of $\delta^{13} \mathrm{C}$ is more informative. The oxygen isotope data of brachiopods point at stable warm climate through the Llandovery in the East Baltic (Heath et al. 1998).

A sudden negative shift in $\delta^{13} \mathrm{C}$ down to $-1 \%$ is recorded at the base of the Rumba Formation in the Estonian Kirikuküla and Ikla cores (Kaljo \& Martma 2000). The reason for this shift is not clear, though primary bioproductivity fall may contribute to it.

\section{Eustasy, water depth, and redox conditions}

Eustasy influenced the marine redox conditions through changes in water depth or indirectly by shaping the basin and delimiting its areal extent. The early Telychian transgression coincided with the beginning of the oxygenation of deep shelf waters, but we have no grounds to claim that deepening of water was the process that caused overturn of the oxygen regime (Fig. 8B).

Different marine researchers (Thunell et al. 2000) have joined the relationship between water depth, organic carbon flux to the sea bed, and primary bioproductivity of surficial waters into an empirical formula. For example, the late Aeronian regression and the corresponding decrease in water depth increased the amount of organic carbon flux to the sediment surface. This supposedly favoured the anoxic conditions in the deep shelf, though the maximum of the primary bioproductivity was over by that time. The Telychian transgression and increase in water depth, on the other hand, reduced the amount of organic carbon flux reaching the sea floor and supported the oxic conditions in the nearbottom waters. The transgression may also influence the sedimentation rate by slowing it, thereby favouring red bed formation. In early Velise time the shift of the red facies from Latvia to Saaremaa was contemporaneous with the second pulse of the transgression (Kiipli et al. 2002). The Viki core shows how deepening of water at the Rumba-Velise boundary changed redox conditions of the sediment. At the beginning of Velise time the sedimentation rate, carbon flux, and oxygen utilization decreased, causing the formation of red clays replacing the greyish limy sediments of the Rumba Formation. Altogether, eustasy played some role in amplifying the redox conditions in the shelf, but it was not a direct cause of the oxic/anoxic overturn in the Aeronian-Telychian transition. 


\section{Processes governing Aeronian-Telychian changes}

From the above discussion the following conclusions can be drawn: 1) the Aeronian was a time of increased primary bioproductivity. High primary bioproductivity played an important role in triggering the anoxic regime of deep water; 2) the Telychian oxygenation of deep water was caused by low primary bioproductivity; 3) extra oxygen to deep waters did not come from the direction of the ocean deep, because the distal shelf sediments were dark-coloured, which does not point to their formation in the oxic environment. The mechanism governing the Aeronian and Telychian changes is hypothesized on the basis of the named presumptions.

The East Baltic Basin was situated in the southwestern part of the Baltica Craton, which in the Llandovery extended from the equatorial region to 20-30 southern latitude (Cocks 1993; Kiessling et al. 2003). By the Wenlock the Baltic Craton was centred at the equator (Ziegler et al. 1977; McKerrow 1988; Torsvik et al. 1992). During the Ordovician and Silurian, Baltica drifted from the region of northwesterlies to southeasterly trade winds, performing a counterclockwise rotation. The changing wind regime in the coastlines of the Baltic Basin might have caused an alternation of upwellings and downwellings (Fig. 9). The models on wind-driven upwellings are presented by Parrish (1982) and Moore et al. (1993). In the Aeronian the upwelling lifted nutrient-rich and oxygendepleted waters from the ocean deep to the shelf and induced high primary bioproductivity in surficial waters. Remineralization of organic carbon intensified oxygen deficiency and favoured the accumulation of organic-rich sediment in the deep shelf. The Aeronian was a period of arid climate, as evidenced by lagoonal dolomites of mainland Estonia. It is likely that in the mid-Llandovery the East Baltic was located at about $24^{\circ}$ southern latitude as this is the zone of deserts where dry air falls down. In the Telychian the downwelling of sea water supposedly took place. Contrary to the Aeronian, the wind-induced downwelling gathered the oxygen-rich but nutrient-depleted surficial waters and directed them towards the sea bottom in shelf areas. The primary bioproductivity of that time decreased, and bottom waters of the deep shelf became oxygenated, causing the formation of red sediments. Telychian eustatic high sea level and rotational stand of the craton supposedly fixed the Baltic Basin so that southeasterly trade winds blew towards the East Baltic coast under a suitable angle, generating the downwelling (Fig. 9).

The model presented here deals with local and regional processes. The Silurian models of Jeppsson (1990), Aldridge et al. (1993), Wenzel \& Joachimski (1996), and Bickert et al. (1997) find evidence for sedimentary, geochemical, and faunal periodical changes from global processes, such as oceanic overturns, icehouse-greenhouse alternations related to atmospheric $\mathrm{CO}_{2}$, and glaciations. These processes are of great importance, yet do not explain all phenomena recorded in geological sequences. Therefore the present model provides a new possible mechanism for describing the genesis of sediments. 


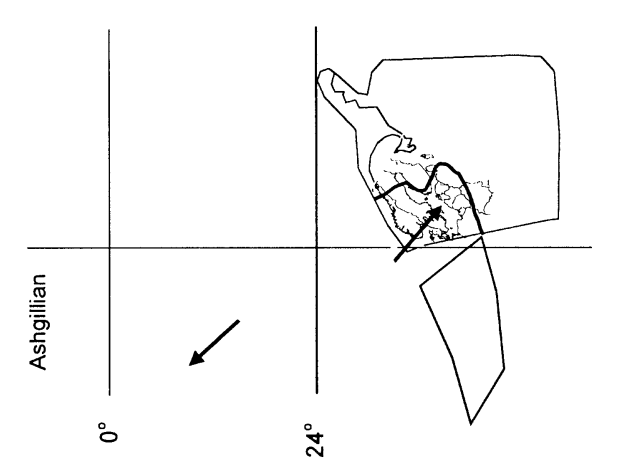

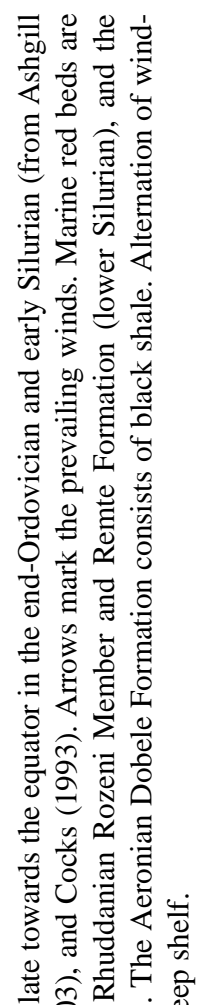

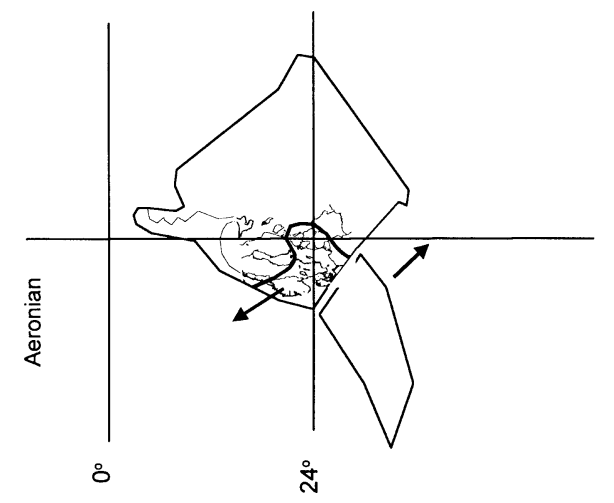

20

שृ

๙ิ

o

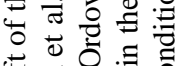

害势

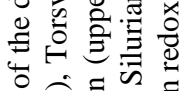

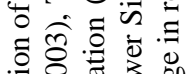

을 过苛

产宁语

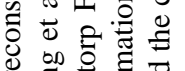

on o

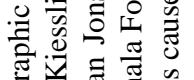

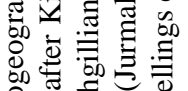

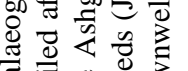

들 Ð

응

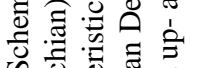

น 음

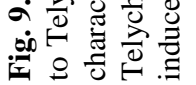




\section{CONCLUSIONS}

1. The Aeronian black shales formed in anoxic sedimentary and anoxic nearbottom water conditions in the deep shelf. The oxygen content below the mixing zone decreased abruptly.

2. The Telychian red sediments with hematite and goethite point at an oxygenating environment in deep shelf bottom waters and sediment. The oxygen profile below the surficial mixing zone had a smooth depthdependent decline. Dark grey sediments in the offshore deep shelf (in western Lithuania and Kaliningrad District) indicate that the flux of free oxygen could not be from the side of ocean deep waters, denying the inversion of the oxygen regime of the ocean of that time.

3. High primary bioproductivity in the Aeronian was suggested considering organic-carbon-rich black shale in the deep shelf contemporaneous with micritic limestone, large-scale chertification, barite occurrences, and a mild positive excursion in $\delta^{13} \mathrm{C}$ in the shallow shelf carbonate facies.

4. The Telychian rocks lack indicators of high primary productivity characteristic of the Aeronian. Consequently, in the Telychian primary bioproductivity was lower than in the Aeronian.

5. The mechanism supposedly regulating the primary bioproductivity and oxygen content of bottom waters and sediment of the deep shelf was alternation of wind-induced up- and downwellings. Upwelling in the Aeronian brought nutrient-rich and oxygen-depleted waters from the ocean deep to the shelf, generating high primary productivity and anoxic deep shelf environment. Downwelling in the Telychian gathered nutrient-poor but oxygen-rich surface waters, causing low primary bioproductivity. As a result, the oxygenation of bottom waters and sediment favoured red bed formation in the deep shelf in the Telychian.

6. The sedimentation rate in the deep shelf was low in the Aeronian as well as in the Telychian. Its oscillations were too small to influence the burial of organic carbon and consequent redox conditions in the deep shelf.

7. Drift of the Baltica Plate through different climatic zones and prevailing winds was responsible for the alternation of up- and downwellings. Eustasy probably affected the configuration of the basin, thereby being related to the up- and downwellings and redox changes.

The present model shows the importance of wind-driven hydrologic movements related to the palaeogeographic location of the continental plate. The proposed mechanism can be responsible for the change in water chemistry of the deep shelf influencing the sediment composition. 


\section{ACKNOWLEDGEMENTS}

This work was financially supported by the Estonian Ministry of Education (project No. 0332088s02) and Estonian Science Foundation (grant No. 5921). The author thanks T. Kiipli for interesting discussions, reviewers H. Nestor and L. Bityukova for revising the manuscript and making valuable comments, K. Orlova and T. Kallaste for help with XRF analysis.

APPENDIX

\section{THE AVERAGE SEDIMENTATION RATE FOR THE TELYCHIAN OF THE AIZPUTE CORE}

Tromp et al. (1995) have distinguished the sedimentation rate as the leading variable in the early diagenetic model for the modern ocean. The accumulation rate is equivalent to the sedimentation rate if hiatuses in the rock section are lacking. Sedimentation in the Telychian in the Aizpute core of West Latvia was permanent from the lower boundary at a depth of 969-930 m. At this depth the Wenlock graptolite Cyrtograptus murchisoni appears (Loydell et al. 2003), revealing a gap in section corresponding to the insectus and centrifugus zones. The gap is about $15 \mathrm{~m}$ according to the graphical correlation between depths of metabentonites in the Viki and Aizpute cores (T. Kiipli \& Kallaste 2002). The proposed thickness of the Telychian sequence is $54 \mathrm{~m}$. The sedimentation rate was found by dividing the thickness of the Telychian section by its duration of 4 million years (Tucker \& McKerrow 1995; Kaljo et al. 1998), increasing the present-day thickness on account of porosity change according to the equation (Berner 1980)

$$
(1-\varnothing) /\left(1-\emptyset_{0}\right)=h_{0} / h
$$

where $\varnothing$ and $\emptyset_{0}$ are the present and past porosities, respectively, and $h$ and $h_{0}$ are the thickness of the yearly layer of the present and past. The average porosity of the present-day rock $\varnothing=20 \%$ was used (Table 2 ); the initial porosity $\emptyset_{0}=75 \%$ was taken after Tromp et al. (1995). The thickness of the yearly layer obtained from the calculation using the thickness of $54 \mathrm{~m}$ was: $54 \times 10^{2} / 4 \times 10^{6}=0.00135 \mathrm{~cm}$, which gave the sedimentation rate: $(1-0.2) /(1-0.75) \times 0.00135=0.0043 \mathrm{~cm} / \mathrm{y}$.

\section{REFERENCES}

Aldridge, R. J., Jeppsson, L. \& Dorning, K. J. 1993. Early Silurian oceanic episodes and events. J. Geol. Soc. London, 150, 501-513.

Bassett, M. G., Kaljo, D. \& Teller, L. 1989. The Baltic region. In Global Standard for the Silurian System (Holland, C. H. \& Bassett, M. G., eds.), Nat. Mus. Wales Geol. Ser., 9, 158-170. 
Berger, W. H. \& Vincent, E. 1986. Deep-sea carbonates. Reading the carbon-isotope signal. Geol. Rundsch., 75, 249-269.

Berner, R. 1971. Principles of Chemical Sedimentology. McGraw-Hill, New York.

Berner, R. 1980. Early Diagenesis. A Theoretical Approach. Princeton University Press, N. J.

Berry, W. B. N., Wilde, P. \& Quinby-Hunt, M. S. 1989. Paleozoic (Cambrian through Devonian) anoxitropic biotopes. Palaeogeogr. Palaeoclimatol. Palaeoecol., 74, 3-13.

Bickert, T., Pätzold, J., Samtleben, C. \& Munnecke, A. 1997. Paleoenvironmental changes in the Silurian indicated by stable isotopes in brachiopod shells from Gotland, Sweden. Geochim. Cosmochim. Acta, 61, 2717-2730.

Bishop, J. K. B. 1988. The barite-opal-organic carbon association in oceanic particulate matter. Nature, 332, 341-343.

Cocks, L. R. M. 1993. Triassic pebbles, derived fossils and the Ordovician to Devonian palaeogeography of Europe. J. Geol. Soc. London, 150, 219-226.

De Lange, G. J., Van Os, B., Pruysers, P. A., Middelburg, J. J., Castradori, D., Van Santvoort, P., Müller, P. J., Eggenkamp, H. \& Prahl, F. G. 1994. Possible early diagenetic alteration of palaeo proxies. In Carbon Cycling in the Glacial Oceans. Constraints on the Ocean's Role in Global Change (Zahn, R., Pedersen, T. F., Kaminski, M. A. \& Labeyrie, L., eds.), pp. 225-258. NATO ASI Series, Springer-Verlag, Berlin.

Dymond, J., Suess, E. \& Lyle, M. 1992. Barium in deep-sea sediment: a geochemical proxy for paleoproductivity. Paleoceanography, 7, 163-181.

Einasto, R. 1986. Main stages of development and facies models of the East Baltic Silurian pericontinental basin. In Theory and Practice of Ecostratigraphy (Kaljo, D. \& Klaamann, E., eds.), pp. 37-54. Valgus, Tallinn (in Russian).

Froelich, P. N., Klinkhammer, G. P., Bender, M. L., Luedtke, N. A., Heath, G. R., Cullen, D., Dauphin, P., Hammond, D., Hartman, B. \& Maynard, V. 1979. Early oxidation of organic matter in pelagic sediments of the eastern equatorial Atlantic: suboxic diagenesis. Geochim. Cosmochim. Acta, 43, 1075-1090.

Gailite, L. K., Ulst, R. Ž. \& Yakovleva, V. I. 1987. Stratotipicheskiye i tipovye razrezy silura Latvii. Zinatne, Riga (in Russian).

Gromet, L. P., Dymek, R., Haskin, L. A. \& Korotev, R. 1984. The North American Shale composite: its compilation, major and trace element characteristics. Geochim. Cosmochim. Acta, 48, 2469-2482.

Heath, R. J., Brenchley, P. J. \& Marshall, J. D. 1998. Early Silurian carbon and oxygen stable-isotope stratigraphy of Estonia: implications for climate change. In Silurian Cycles. Linkages of Dynamic Stratigraphy with Atmospheric, Oceanic and Tectonic Changes (Landing, E. \& Johnson, M. E., eds.), $N$ Y State Mus. Bull., 491, 313-326.

Holland, C. H. \& Bassett, M. G. (eds.). 2002. Telychian rocks of the British Isles and China (Silurian, Llandovery Series): an experiment to test precision in stratigraphy. Nat. Mus. Wales Geol. Ser., 21.

Jeppsson, L. 1990. An oceanic model for lithological and faunal changes tested on the Silurian record. J. Geol. Soc. London, 147, 663-674.

Johnson, M. E., Baarli, B. G., Nestor, H., Rubel, M. \& Worsley, D. 1991. Eustatic sea-level patterns from the Lower Silurian (Llandovery Series) of southern Norway and Estonia. Geol. Soc. Am. Bull., 103, 315-335.

Jürgenson, E. 1958. Forms of silica in Ordovician and Silurian carbonate rocks in Soviet Estonia. Geol. Inst. Uurimused II, pp. 87-92. Eesti Riiklik Kirjastus, Tallinn (in Russian).

Jürgenson, E. 1974. Distribution of the authigenic silica in the East Baltic Silurian deposits. Proc. Estonian. Acad. Sci. Chem. Geol., 23, 322-331 (in Russian).

Jürgenson, E. 1988. Deposition of the Silurian Beds in the Baltic. Valgus, Tallinn (in Russian).

Kaljo, D. (ed.). 1970. Silur Estonii. Valgus, Tallinn (in Russian). 
Kaljo, D. 1977. Structural and facial subdivisions on the East Baltic Silurian basin. In Facies and Fauna of the Baltic Silurian (Kaljo, D., ed.), pp. 6-13. Academy of Sciences of the Estonian SSR, Tallinn (in Russian).

Kaljo, D., Kiipli, T. \& Martma, T. 1998. Correlation of carbon isotope events and environmental cyclicity in the East Baltic Silurian. N Y State Mus. Bull., 491, 297-312.

Kaljo, D. \& Martma, T. 2000. Carbon isotopic composition of Llandovery rocks (East Baltic Silurian) with environmental interpretation. Proc. Estonian Acad. Sci. Geol., 49, 267-283.

Kiessling, W., Flügel, E. \& Golonka, J. 2003. Phanerozoic carbonate platform sedimentation. Lethaia, 36, 195-225.

Kiipli, E. 1997. Geochemistry of Llandovery black shales in the Aizpute-41 core, West Latvia. Proc. Estonian Acad. Sci. Geol., 46, 127-145.

Kiipli, E. 1998. Indexes of palaeosea chemical environments in deep shelf claystones. Case study of Lower Silurian section in Aizpute-41 core, west Latvia. Dissertationes Geologicae Universitatis Tartuensis. Unpublished MSc Thesis.

Kiipli, E., Kallaste, T. \& Kiipli, T. 2000a. Hematite and goethite in Telychian marine red beds of the East Baltic. GFF, 122, 281-286.

Kiipli, E., Kiipli, T. \& Kallaste, T. 2000b. Early diagenetic chalcopyrite occurrences in Telychian marine red beds of West Estonia and West Latvia. Proc. Estonian Acad. Sci. Geol., 49, 294-307.

Kiipli, E., Kiipli, T. \& Kallaste, T. 2002. Correlation between deep and shallow shelf on the basis of O-bentonite, East Baltic. In The Fifth Baltic Stratigraphical Conference, Extended Abstracts (Satkunas, J. \& Lazauskiene, J., eds.), pp. 77-80. Vilnius.

Kiipli, E., Kiipli, T. \& Kallaste, T. 2004. Bioproductivity rise in the East Baltic epicontinental sea in the Aeronian (Early Silurian). Palaeogeogr. Palaeoclimatol. Palaeoecol., 205, 255-272.

Kiipli, T. \& Kallaste, T. 2002. Correlation of Telychian sections from shallow to deep sea facies in Estonia and Latvia based on the sanidine composition of bentonites. Proc. Estonian Acad. Sci. Geol., 51, 143-156.

Kiipli, T., Batchelor, R. A., Bernal, J. P., Cowing, C., Hagel-Brunnström, M., Ingham, M. N., Johnson, D., Kivisilla, J., Knaack, C., Kump, P., Lozano, R., Michiels, D., Orlova, K., Pirrus, E., Rousseau, R. M., Ruzicka, J., Sandström, H. \& Willis, J. P. 2000. Seven sedimentary rock reference samples from Estonia. Oil Shale, 17, 215-223.

Krauskopf, K. B. \& Bird, D. K. 1995. Introduction to Geochemistry. McGraw-Hill, Inc., New York.

Kroopnick, P. M. 1985. The distribution of ${ }^{13} \mathrm{C}$ of $\Sigma \mathrm{CO}_{2}$ in the world oceans. Deep-Sea Res., 32, $57-84$.

Loydell, D. K. 1998. Early Silurian sea-level changes. Geol. Mag., 135, 447-471.

Loydell, D. K., Männik, P. \& Nestor, V. K. 2003. Integrated biostratigraphy of the lower Silurian of the Aizpute-41 core, Latvia. Geol. Mag., 140, 205-229.

Männil, R. 1966. Evolution of the Baltic Basin During the Ordovician. Valgus, Tallinn (in Russian).

McKerrow, W. S. 1988. The development of the Iapetus Ocean from the Arenig to the Wenlock. In The Caledonian-Appalachian Orogen (Harris, A. L. \& Fettes, D. J., eds.). Geol. Soc. Spec. Publ., 38, 405-412.

Moore, G. T., Hayashida, D. N. \& Ross, C. A. 1993. Late Early Silurian (Wenlockian) general circulation model - generated upwelling, graptolitic black shales, and organic-rich source rocks - An accident of plate tectonics? Geology, 21, 17-20.

Murdmaa, I. O. 1987. Fatsii okeanov. Nauka, Moscow (in Russian).

Nestor, H. 1972. On the stratigraphic range of the beds with Pentamerus oblongus and on the nature of the Late Llandoverian transgression in North Europe. ENSV TA Toim. Keemia Geol., 21, 344-350 (in Russian).

Nestor, H. 1997. Silurian. In Geology and Mineral Resources of Estonia (Raukas, A. \& Teedumäe, A., eds.), pp. 89-106. Estonian Academy Publishers, Tallinn. 
Nestor, H. \& Einasto, R. 1997. Ordovician and Silurian carbonate sedimentation basin. In Geology and Mineral Resources of Estonia (Raukas, A. \& Teedumäe, A., eds.), pp. 192-204. Estonian Academy Publishers, Tallinn.

Nestor, H. \& Nestor, V. 2002. Stratigraphic gaps, and problems of the Telychian (upper Llandovery, Silurian) boundaries in the Northern East Baltic area. In The Fifth Baltic Stratigraphical Conference, Extended Abstracts (Satkunas, J. \& Lazauskiene, J., eds.), 147-149. Vilnius.

Nestor, H., Einasto, R., Männik, P. \& Nestor, V. 2003. Correlation of lower-middle Llandovery sections in central and southern Eatonia and sedimentation cycles of lime mud. Proc. Estonian Acad. Sci. Geol., 52, 3-27.

Nestor, V. 1994. Early Silurian chitinozoans of Estonia and North Latvia. Academia, 4, Estonian Academy Publishers, Tallinn.

Parrish, J. T. 1982. Upwelling and petroleum source beds, with reference to Paleozoic. Am. Ass. Petroleum Geol. Bull., 66, 750-774.

Paškevičius, J. 1997. The Geology of the Baltic Republics. Vilnius University, Geological Survey of Lithuania, Vilnius.

Poprawa, P., Šliaupa, S., Stephenson, R. \& Lazauskiene, J. 1999. Late Vendian-Early Palaeozoic evolution of the Baltic Basin: regional tectonic implications from subsidence analysis. Tectonophysics, 314, 219-239.

Raukas, A. \& Teedumäe, A. (eds.). 1997. Geology and Mineral Resources of Estonia. Estonian Academy Publishers, Tallinn.

Reintam, L. 2003. Current primary pedogenesis on Devonian sandstone in southern Estonia. Proc. Estonian Acad. Sci. Geol., 52, 28-41.

Scotese, C. R. 2001. Atlas of Earth History. PALEOMAP Project, Arlington, Texas.

Teedumäe, A., Kallaste, T. \& Kiipli, T. 2003. Comparative study of dolomites of different genesis (Raikküla Formation, Silurian; Estonia). Proc. Estonian Acad. Sci. Geol., 52, 113-127.

Thunell, R. C., Varela, R., Llano, M., Collister, J., Muller-Karger, F. \& Bohrer, R. 2000. Organic carbon fluxes, degradation, and accumulation in an anoxic basin: sediment trap results from the Cariaco Basin. Limnol. and Oceanogr., 45, 300-308.

Torsvik, T. H. \& Rehnström, E. F. 2003. The Tornquist Sea and Baltica-Avalonia docking. Tectonophysics, 362, 67-82.

Torsvik, T. H., Smethurst, M. A., Van der Voo, R., Trench, A., Abrahamsen, N. \& Halvorsen, E. 1992. Baltica. Asynopsis of Vendian-Permian palaeomagnetic data and their palaeotectonic implications. Earth Sci. Rev., 33, 133-152.

Tromp, T. K., Van Cappellen, P. \& Key, R. M. 1995. A global model for the early diagenesis of organic carbon and organic phosphorus in marine sediments. Geochim. Cosmochim. Acta, 59, 1259-1284

Tucker, R. D. \& McKerrow, W. S. 1995. Early Paleozoic chronology: a review in light of new U-Pb zircon ages from Newfoundland and Britain. Can. J. Earth Sci., 32, 368-379.

van Ranst, E., Verloo, M., Demeyer, A. \& Pauwels, J. M. 1999. Manual for the Soil Chemistry and of Fertility Laboratory. Analytical Methods for Soils and Plants, Equipment and Management of Consumables. University of Ghent, Gent, Belgium.

Wenzel, B. \& Joachimski, M. M. 1996. Carbon and oxygen isotopic composition of Silurian brachiopods (Gotland/Sweden): palaeoceanographic implications. Palaeogeogr. Palaeoclimatol. Palaeoecol., 122, 143-166.

Worsley, D., Aarhus, N., Bassett, M., Howe, M., Mork, A. \& Olaussen, S. 1982. The Silurian succession of the Oslo region. Paleont. Contrib. Univ. of Oslo, 27.

Ziegler, A. M., Hansen, K. S., Johnson, M. E., Kelly, M. A., Scotese, C. R. \& Van Der Voo, R. 1977. Silurian continental distributions, paleogeography, climatology, and biogeography. Tectonophysics, 40, 13-51. 


\title{
Redokstingimuste muutused Ida-Balti basseini sügaval šelfil Aeronis ja Telychis (Vara-Siluris)
}

\section{Enli Kiipli}

\begin{abstract}
Alam-Siluri Aeroni-vanusega geoloogilises läbilõikes esinevad Lääne-Lätis mustad orgaanilise aine rikkad savikivimid, Telychis punased ja rohekashallid savikivimid. Need kivimid on moodustunud sügaval šelfil settinud setetest. Värvuste erinevus viitab settimisaegsete redokstingimuste erinevusele. Redokstingimustest lähtuvat sette varadiageneesi kujundasid järgmised faktorid: vaba hapnik põhjalähedases merevees, primaarsest bioproduktsioonist tulenev orgaanilise süsiniku voog merepõhja ning sette settimise kiirus. Uurimistööst järeldus, et vastupidiselt Aeroni-aegsele suurele primaarsele bioproduktsioonile oli Telychi-aegne bioproduktsioon madal. See tekitas hapnikusisalduste erinevuse põhjalähedases merevees. Bioproduktsioonide erinevust reguleerisid tõusu- ja langevhoovused. Aeronis tõi tõusuhoovus sügavamatest ookeanikihtidest šelfile hapnikuvaese, kuid toitainerikka vee. Telychis kogunes hapnikurikas, kuid toitainevaene pindmine veekiht, mis suundus sügavusse. Tõusu- ja langevhoovuste vaheldumise põhjuseks oli Balti mandrilaama ja selle lääneserval asuva Balti basseini triiv läbi erinevate tuulesuundadega kliimavöötmete.

Sette settimise kiirus ei olnud Aeroni ja Telychi redokstingimuste erinevuse põhjuseks, kuna oli mõlemal ajal kas võrdselt madal või Aeronis väiksem kui Telychis. Väiksem settimiskiirus soodustaks aga pigem punavärvilisuse kui Aeronis oleva musta kilda teket. Arvutuslik settimiskiirus Aizpute puuraugus oli $4 \mathrm{~cm} 1000$ aasta kohta Telychi läbilõike jaoks.
\end{abstract}

